\title{
Synthesis, Structure, and Properties of the Layered Oxide Chalcogenides $\mathrm{Sr}_{2} \mathrm{CuO}_{2} \mathrm{Cu}_{2} \mathrm{~S}_{2}$ and $\mathrm{Sr}_{2} \mathrm{CuO}_{2} \mathrm{Cu}_{2} \mathrm{Se}_{2}$
}

\author{
Jack N. Blandy, ${ }^{\dagger \neq}$ Shuai Liu, ${ }^{\dagger, \S}$ Catherine F. Smura, ${ }^{\dagger}$ Simon J. Cassidy, ${ }^{\dagger}$ Daniel N. Woodruff, ${ }^{\dagger}$ \\ John E. McGrady, ${ }^{\dagger}$ and Simon J. Clarke*, ${ }^{\dagger}$ \\ ${ }^{\dagger}$ Department of Chemistry, Inorganic Chemistry Laboratory, University of Oxford, South Parks Road, Oxford OX1 3QR, U.K. \\ ${ }^{\ddagger}$ Diamond Light Source Ltd., Harwell Science and Innovation Campus, Didcot OX11 0DE, U.K. \\ ${ }^{\S}$ College of Chemistry and Chemical Engineering, Anhui University, Hefei 230601, People’s Republic of China
}

Supporting Information

\begin{abstract}
The structures of two new oxide chalcogenide phases, $\mathrm{Sr}_{2} \mathrm{CuO}_{2} \mathrm{Cu}_{2} \mathrm{~S}_{2}$ and $\mathrm{Sr}_{2} \mathrm{CuO}_{2} \mathrm{Cu}_{2} \mathrm{Se}_{2}$, are reported, both of which contain infinite $\mathrm{CuO}_{2}$ planes containing $\mathrm{Cu}^{2+}$ and which have $\mathrm{Cu}^{+}$ions in the sulfide or selenide layers. Powder neutron diffraction measurements show that $\mathrm{Sr}_{2} \mathrm{CuO}_{2} \mathrm{Cu}_{2} \mathrm{Se}_{2}$ exhibits long-range magnetic ordering with a magnetic structure based on antiferromagnetic interactions between nearest-neighbor $\mathrm{Cu}^{2+}$ ions, leading to a $\sqrt{2 a} \times \sqrt{2 a}$ $\times 2 c$ expansion of the nuclear cell. The ordered moment of $0.39(6) \mu_{\mathrm{B}}$ on the $\mathrm{Cu}^{2+}$ ions at $1.7 \mathrm{~K}$ is consistent with the value predicted by density functional theory calculations. The compounds are structurally related to the cuprate superconductors and may also be considered as analogues of the

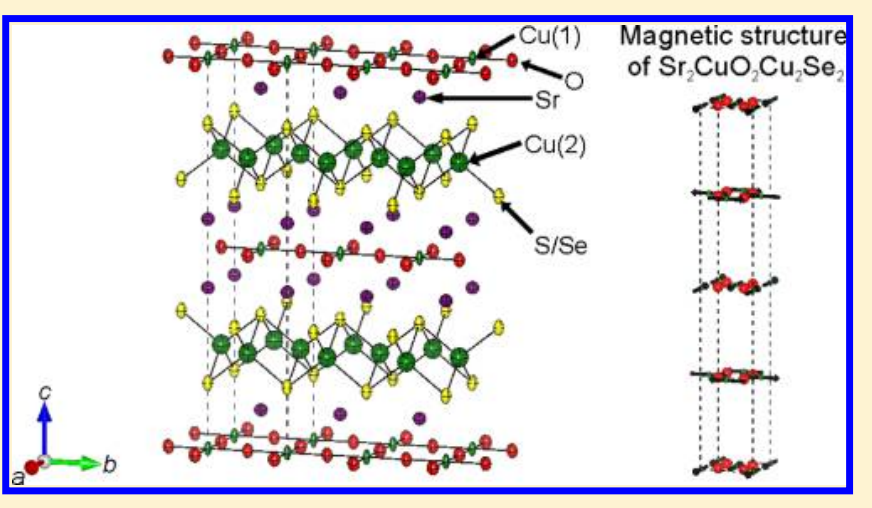
parent phases of this class of superconductor such as $\mathrm{Sr}_{2} \mathrm{CuO}_{2} \mathrm{Cl}_{2}$ or $\mathrm{La}_{2} \mathrm{CuO}_{4}$. In the present case, however, the top of the chalcogenide-based valence band is very close to the vacant $\mathrm{Cu}^{2+} 3 \mathrm{~d}$ states of the conduction band, leading to relatively high measured conductivity.
\end{abstract}

\section{INTRODUCTION}

Oxide chalcogenides of the general formula $\mathrm{A}_{2} \mathrm{MO}_{2} \mathrm{X}_{2} \mathrm{Ch}_{2}$ (where $\mathrm{A}=\mathrm{Sr}, \mathrm{Ba} ; \mathrm{M}=$ first-row transition metal; $\mathrm{X}=\mathrm{Cu}$, $\mathrm{Ag}$; and $\mathrm{Ch}=\mathrm{S}, \mathrm{Se}$ ) were first reported by $\mathrm{Zhu}$ and Hor ${ }^{1,2}$ and they typically adopt the $\mathrm{Sr}_{2} \mathrm{Mn}_{3} \mathrm{Sb}_{2} \mathrm{O}_{2}$ structure ${ }^{3}$ shown in Figure 1 . Here, the metal ions, $\mathrm{M}$ and $\mathrm{X}$, are segregated into planar $\mathrm{MO}_{2}$ and anti-PbO-type $\mathrm{X}_{2} \mathrm{Ch}_{2}$ layers. Since their initial discovery, this family of compounds and their relatives has expanded rapidly, to the point where changes in the structure and properties can now be correlated meaningfully with the

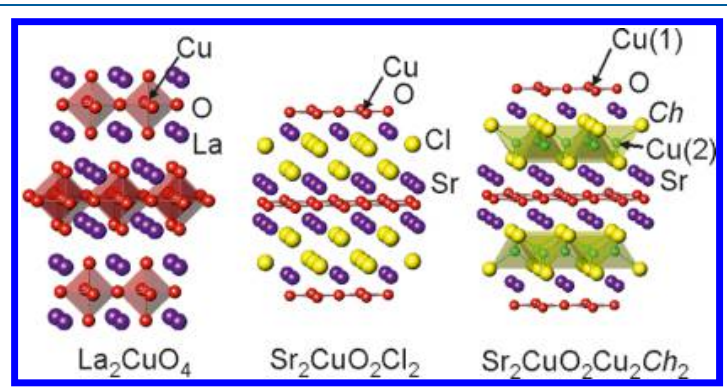

Figure 1. Comparison of the crystal structures of $\mathrm{La}_{2} \mathrm{CuO}_{4}$, $\mathrm{Sr}_{2} \mathrm{CuO}_{2} \mathrm{Cl}_{2}$, and $\mathrm{Sr}_{2} \mathrm{CuO}_{2} \mathrm{Cu}_{2} \mathrm{Ch}_{2}$, where $\mathrm{Ch}=\mathrm{S}$, Se. The two distinct copper sites in $\mathrm{Sr}_{2} \mathrm{CuO}_{2} \mathrm{Cu}_{2} \mathrm{Ch}_{2}$ are identified as $\mathrm{Cu}(1)$ in the oxide layer and $\mathrm{Cu}(2)$ in the chalcogenide layer. chemistry of the transition element in the oxide layer. ${ }^{4}$ When the oxide layer of the $\mathrm{A}_{2} \mathrm{MO}_{2} \mathrm{X}_{2} \mathrm{Ch}_{2}$ compounds contains $\mathrm{Mn}$ ions, as in $\mathrm{Sr}_{2} \mathrm{MnO}_{2} \mathrm{Cu}_{1.5} \mathrm{~S}_{2}$ and $\mathrm{Sr}_{2} \mathrm{MnO}_{2} \mathrm{Cu}_{1.5} \mathrm{Se}_{2}$ for example, ${ }^{5,6}$ the compounds are coinage-metal deficient, the oxidation state of the transition metal exceeds $+2\left(\mathrm{Mn}^{2+/ 3+}\right)$, and the magnetic ordering is dominated by ferromagnetic interactions between localized moments in the $\mathrm{MnO}_{2}$ layers. A further $\sim 10 \%$ of $\mathrm{Cu}$ in $\mathrm{Sr}_{2} \mathrm{MnO}_{2} \mathrm{Cu}_{1.5} \mathrm{~S}_{2}$ can be removed by topotactic deintercalation, leading to a further increase in the average $\mathrm{Mn}$ oxidation state and dramatic changes in both the crystal and magnetic structures. ${ }^{7}$ With less oxidizable later transition-metal ions such as $\mathrm{Co}^{2+}, \mathrm{Ni}^{2+}$, and $\mathrm{Zn}^{2+}$, stoichiometric compositions are obtained and antiferromagnetic ordering prevails in the $\mathrm{MO}_{2}$ planes in cases where an ordered moment is present. The $\mathrm{Zn}$ member of the family $\mathrm{Sr}_{2} \mathrm{ZnO}_{2} \mathrm{Cu}_{2} \mathrm{~S}_{2}$ is a yellow direct band gap semiconductor $\left(E_{\mathrm{g}}\right.$ $\approx 2.7 \mathrm{eV}),{ }^{8}$ while the $\mathrm{Ni}$ analogue exhibits complex structural and magnetic changes at low temperatures, which are not yet fully resolved. ${ }^{9}$ The Co phase $\mathrm{Sr}_{2} \mathrm{CoO}_{2} \mathrm{Cu}_{2} \mathrm{~S}_{2}{ }^{2}$ has an ordered moment with a large orbital component, ${ }^{10}$ but $\mathrm{Sr}_{2} \mathrm{CoO}_{2} \mathrm{Cu}_{2} \mathrm{~S}_{2}$ is also susceptible to partial oxidation in air by topotactic deintercalation of $\mathrm{Cu} .{ }^{10}$ For a given transition metal, $\mathrm{M}$, the

Received: September 21, 2018

Published: November 27, 2018 
inherent compositional flexibility of the crystal structure allows for further tuning of the physical properties by chemical substitutions on the electropositive metal (e.g. Ba for Sr), ${ }^{10-12}$ coinage metal (e.g. Ag for $\mathrm{Cu}),{ }^{11,13,14}$ and chalcogenide sites (e.g. Se for S). ${ }^{6}$

In this work, we report the synthesis and properties of two new members of this series, the oxide selenide $\mathrm{Sr}_{2} \mathrm{CuO}_{2} \mathrm{Cu}_{2} \mathrm{Se}_{2}$ and its oxide sulfide analogue $\mathrm{Sr}_{2} \mathrm{CuO}_{2} \mathrm{Cu}_{2} \mathrm{~S}_{2}$, both of which contain infinite $\left[\mathrm{CuO}_{2}\right]^{2-}$ planes similar to those in the cuprate high-temperature superconductors ${ }^{15}$ and related phases such as $\mathrm{Sr}_{2} \mathrm{CuO}_{2} \mathrm{Cl}_{2} .{ }^{16} \mathrm{Li}$ et al. have recently reported the synthesis of the analogous barium oxide selenide phase $\mathrm{Ba}_{2} \mathrm{CuO}_{2} \mathrm{Cu}_{2} \mathrm{Se}_{2}$, ${ }^{12}$ using a high-pressure synthesis. We report here that phase-pure $\mathrm{Sr}_{2} \mathrm{CuO}_{2} \mathrm{Cu}_{2} \mathrm{Se}_{2}$ may be obtained at ambient pressure. Otzschi et al. ${ }^{17}$ have previously reported the oxide sulfide $\mathrm{Sr}_{2} \mathrm{CuO}_{2} \mathrm{Cu}_{2} \mathrm{~S}_{2}$, but the powder X-ray diffraction (PXRD) pattern revealed that the sample was highly impure, impeding attempts to make a detailed analysis of either structure or magnetism. This impurity reflects the intrinsic difficulty of stabilizing $\mathrm{Cu}^{2+}$ in the presence of a chalcogenide anion, and although we have been unable to resolve this issue entirely, we have been able to use a flux method to produce a sample of $\mathrm{Sr}_{2} \mathrm{CuO}_{2} \mathrm{Cu}_{2} \mathrm{~S}_{2}$ that is almost $80 \mathrm{wt} \%$ pure, sufficient to allow an accurate description of its structure. For both phases, a detailed discussion of the structure and physical properties is complemented by an electronic structure analysis performed using density functional theory (DFT).

\section{EXPERIMENTAL SECTION}

Synthesis. $\mathrm{Sr}_{2} \mathrm{CuO}_{2} \mathrm{Cu}_{2} \mathrm{Se}_{2}$ was prepared on a $5 \mathrm{~g}$ scale. The reactants used were $\mathrm{SrO}$ (prepared by thermal decomposition of $\mathrm{SrCO}_{3}$ (Alfa 99.999\%) at $1100{ }^{\circ} \mathrm{C}$ ), $\mathrm{Cu}$ (Alfa, $99.999 \%$ ), and Se (Alfa $99.999 \%)$ in the molar ratio 2:3:2. The reactants were ground together, pelletized $(0.4 \mathrm{GPa})$, loaded into an alumina crucible, and flame-sealed in an evacuated silica ampoule. The pellet was then heated to $500{ }^{\circ} \mathrm{C}$ at $10{ }^{\circ} \mathrm{C} \min ^{-1}$ for $48 \mathrm{~h}$. The sample was then allowed to cool in the furnace, before isolating the product. Laboratory PXRD, after this step, revealed that the sample was contaminated with significant amounts of $\mathrm{SrO}, \mathrm{SrSe}, \mathrm{Cu}_{2} \mathrm{Se}$, and $\mathrm{Cu}_{2} \mathrm{O}$ impurities, so the sample was ground, pelletized, and reheated at $500{ }^{\circ} \mathrm{C}$. This produced a sample that appeared phase-pure by laboratory PXRD. The sample was found to decompose to a mixture of products at temperatures significantly above $500{ }^{\circ} \mathrm{C}$.

For the oxide sulfide analogue, the " $\mathrm{Sr}_{2} \mathrm{CuO}_{2} \mathrm{Cu}_{2} \mathrm{~S}_{2}$ " reactant mixture was prepared by grinding together $\mathrm{SrS}$ [prepared by reaction of $\mathrm{SrCO}_{3}$ (Alfa 99.999\%) with $\mathrm{CS}_{2}$ ], $\mathrm{CuO}$ (Aldrich, 99.99\%), and $\mathrm{Cu}_{2} \mathrm{O}$ in the molar ratio 2:1:1 under an argon atmosphere. The flux mixture was separately prepared by grinding together $\mathrm{NaI}$ (Alfa, 99.98\%) and CsI (Aldrich, 99.99\%) in the molar ratio 0.44:0.56. The prepared " $\mathrm{Sr}_{2} \mathrm{CuO}_{2} \mathrm{Cu}_{2} \mathrm{~S}_{2}$ " reactant mixture and the flux were then ground together in a 1:1 molar ratio, that is, " $\mathrm{Sr}_{2} \mathrm{CuO}_{2} \mathrm{Cu}_{2} \mathrm{~S}_{2}$ ": $0.44 \mathrm{NaI} / 0.56 \mathrm{CsI}$. The loose powder mixture was heated at $500{ }^{\circ} \mathrm{C}$ for $16 \mathrm{~h}$ and then reground and reheated at $500{ }^{\circ} \mathrm{C}$ for $11 \mathrm{~h}$. The flux was then removed by washing the sample in deionized water, and then subsequently in acetone, under suction. This was the only step performed in air. According to XRD measurements, this washing step removed most of the SrS remaining after the initial synthetic step.

Diffraction Measurements. Preliminary structural characterization was carried out using PXRD on a PANalytical Empyrean instrument, operating in Bragg-Brentano geometry and utilizing $\mathrm{Cu}$ $\mathrm{K} \alpha_{1}$ radiation (obtained using a Ge monochromator) or a Philips PW1710 diffractometer with Ni-filtered $\mathrm{Cu} K \alpha_{1} / \alpha_{2}$ radiation. Detailed structural characterization was undertaken on the highresolution synchrotron X-ray powder diffractometer I11 at Diamond, UK. ${ }^{18}$ Powder neutron diffraction (PND) measurements were carried out using the GEM, ${ }^{19}$ POLARIS, ${ }^{20}$ and WISH ${ }^{21}$ diffractometers at the
ISIS Pulsed Neutron Source, UK. The samples were prepared for synchrotron PXRD measurements by mixing them with either amorphous boron or ground glass to minimize absorption and preferred orientation effects. Each sample was then loaded into a 0.5 $\mathrm{mm}$ diameter borosilicate capillary in an argon atmosphere. For measurements using PND, the sample was loaded into a thin-walled vanadium cylinder sealed with an indium gasket. Rietveld refinements against both PND and PXRD data were conducted using the TOPAS Academic version 5 software. ${ }^{22}$

Magnetometry. The magnetic susceptibility of each compound was measured using a Quantum Design MPMS-XL SQUID magnetometer. Batches of powder $(50-100 \mathrm{mg})$ were weighed accurately into gelatin capsules. In each case, prior to measurement of the magnetic susceptibility as a function of temperature, the magnetic moment was measured as a function of field at $300 \mathrm{~K}$. Any nonlinearity in the plot of moment against field was assumed to arise from ferromagnetic impurities. To eliminate the effect of such impurities, measurements of the magnetic moment as a function of temperature were performed at two fields (fields of 4 and $3 \mathrm{~T}$ were used in this work) above the saturation point of the ferromagnetic impurity (where the sample moment varied linearly with field), and the magnetic susceptibility was obtained from the difference between the values of the moment at the two fields.

Resistivity Measurements. The direct current $(\mathrm{dc})$ resistivity of a sintered pellet of $\mathrm{Sr}_{2} \mathrm{CuO}_{2} \mathrm{Cu}_{2} \mathrm{Se}_{2}$ was measured using the fourprobe method. Four copper (0.1 mm diameter; Alfa 99.9985\%) wires were attached to the sintered pellet using silver paste. Measurements were made in the temperature range $15 \leq T(\mathrm{~K}) \leq 300$ with the sample contained in a closed-cycle refrigerator system (AS Scientific Products Ltd) controlled using an Oxford Instruments ITC-4 temperature controller. A current of $1.0 \mathrm{~mA}$ was applied using a Time Electronics $1024 \mathrm{dc}$ current calibrator, and the voltage was measured using a Hewlett Packard HP3478A multimeter.

Computational Details. All DFT calculations were carried out using the VASP software package, ${ }^{23,24}$ version 5.3.5, with the PBE functional $^{25}$ and a plane-wave cutoff of $400 \mathrm{eV}$. A $\sqrt{2 a} \times \sqrt{2 a} \times c$ expansion of the unit cell containing two $\mathrm{Cu}^{2+}$ centers per layer was used throughout for the detailed calculations, and the tetragonal Brillouin zone was sampled on a $4 \times 4 \times 1 \Gamma$-centered grid. ${ }^{26} \mathrm{~A}$ finer $10 \times 10 \times 1 \Gamma$-centered grid was used to generate the density of states (DOS). The effect of the core electrons was incorporated using PAW potentials, ${ }^{27}$ and a Hubbard $U_{\text {eff }}$ value ${ }^{28}$ of $7.0 \mathrm{eV}$ was applied to the $\mathrm{Cu}^{2+}$ centers in the $\mathrm{CuO}_{2}$ layer. A value of $7.0 \mathrm{eV}$ for the Hubbard $U_{\text {eff }}$ at $\mathrm{Cu}^{2+}$ is typical of many studies of $\mathrm{Cu}$ oxides, including the work of $\mathrm{Li}$ et al. on the closely related barium analogue $\mathrm{Ba}_{2} \mathrm{CuO}_{2} \mathrm{Cu}_{2} \mathrm{Se}_{2}$ using the WIEN2K code, ${ }^{12}$ although somewhat smaller values have been used in other contexts $(6.0 \mathrm{eV}$ in Weng et al.'s investigation of $\mathrm{Sr}_{2} \mathrm{CuO}_{2} \mathrm{Cl}_{2}$, for example). ${ }^{29}$ We also tested the effects of smaller values of $U_{\text {eff }}$ (see below and in the Supporting Information).

\section{RESULTS AND DISCUSSION}

Synthesis. A sample of $\mathrm{Sr}_{2} \mathrm{CuO}_{2} \mathrm{Cu}_{2} \mathrm{Se}_{2}$ was made phasepure using stoichiometric reagents as described in the Experimental Section. The synthesis of the sulfide analogue proved more challenging. The use of binary or elemental reagents alone inevitably produced highly impure material, and the flux method described above produced the purest product. PXRD of the sample after one heat treatment showed the transient formation of SrO. PXRD measurements after two heat treatments and before washing away the flux (Figure S1) revealed the absence of $\mathrm{SrO}$ and just the presence of elemental $\mathrm{Cu}, \mathrm{SrS}$, and $\mathrm{SrSO}_{4}$ in a 6:3:1 molar ratio, together with the intended $\mathrm{Sr}_{2} \mathrm{CuO}_{2} \mathrm{Cu}_{2} \mathrm{~S}_{2}$ phase. The ratio of impurities is consistent with them being produced by the competing decomposition reaction of $\mathrm{Sr}_{2} \mathrm{CuO}_{2} \mathrm{Cu}_{2} \mathrm{~S}_{2}$

$$
\left[\mathrm{Sr}_{2} \mathrm{CuO}_{2} \mathrm{Cu}_{2} \mathrm{~S}_{2}\right] \rightarrow 3 \mathrm{Cu}+(1.5) \mathrm{SrS}+(0.5) \mathrm{SrSO}_{4}
$$


This decomposition is an intrinsic difficulty with this phase as noted previously, ${ }^{17}$ and it remains possible that a purer sample might be obtained in a high-pressure reaction of the type employed by $\mathrm{Li}$ et al. in their synthesis of $\mathrm{Ba}_{2} \mathrm{CuO}_{2} \mathrm{Cu}_{2} \mathrm{Se}_{2}$. ${ }^{12}$

Crystal Structures. Analysis of the PXRD data (see the Supporting Information Figures S2 and S3) confirms that both $\mathrm{Sr}_{2} \mathrm{CuO}_{2} \mathrm{Cu}_{2} \mathrm{~S}_{2}$ and $\mathrm{Sr}_{2} \mathrm{CuO}_{2} \mathrm{Cu}_{2} \mathrm{Se}_{2}$ crystallize with the $\mathrm{Sr}_{2} \mathrm{Mn}_{3} \mathrm{Sb}_{2} \mathrm{O}_{2}$ structure in the tetragonal space group, I4/ $\mathrm{mmm}$. Room temperature (RT) PND was performed to analyze the fractional occupancy of the sites, the results of which are shown in Figures 2 and 3, with refined values for the

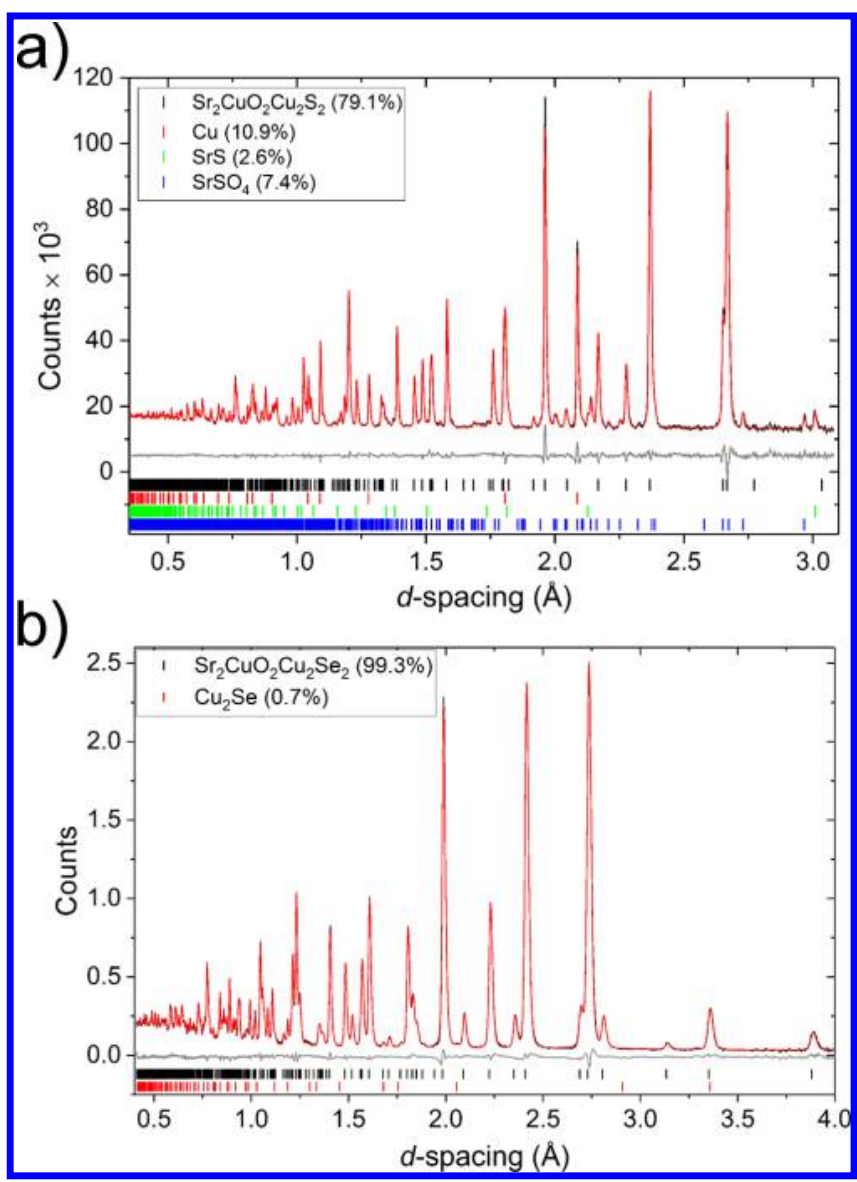

Figure 2. Rietveld analysis of RT PND data collected for (a) $\mathrm{Sr}_{2} \mathrm{CuO}_{2} \mathrm{Cu}_{2} \mathrm{~S}_{2}$ using the "C" bank (average $2 \theta=145^{\circ}$ ) of POLARIS (ISIS) and (b) $\mathrm{Sr}_{2} \mathrm{CuO}_{2} \mathrm{Cu}_{2} \mathrm{Se}_{2}$ using Bank 4 (average $2 \theta=63.6^{\circ}$ ) of GEM (ISIS).

two compounds compared in Table 1. Attempts to refine the occupancy of each of the sites in turn resulted (within the uncertainty in the refinement) in site occupancies of one in each case, and so all the sites were constrained to be fully occupied in the final refinement. In the case of the phase-pure $\mathrm{Sr}_{2} \mathrm{CuO}_{2} \mathrm{Cu}_{2} \mathrm{Se}_{2}$, this constraint is consistent with the reaction stoichiometry, while for the sulfide, it is consistent with the ratio of the decomposition products. Both $\mathrm{Sr}_{2} \mathrm{CuO}_{2} \mathrm{Cu}_{2} \mathrm{~S}_{2}$ and $\mathrm{Sr}_{2} \mathrm{CuO}_{2} \mathrm{Cu}_{2} \mathrm{Se}_{2}$ were also measured as a function of temperature: using PND from 5 to $90 \mathrm{~K}$ for $\mathrm{Sr}_{2} \mathrm{CuO}_{2} \mathrm{Cu}_{2} \mathrm{~S}_{2}$ (to investigate whether there was any structural change associated with a small feature in the magnetic susceptibility-see below) and PXRD from 100 to $300 \mathrm{~K}$ for $\mathrm{Sr}_{2} \mathrm{CuO}_{2} \mathrm{Cu}_{2} \mathrm{Se}_{2}$ (the temperature range available using the

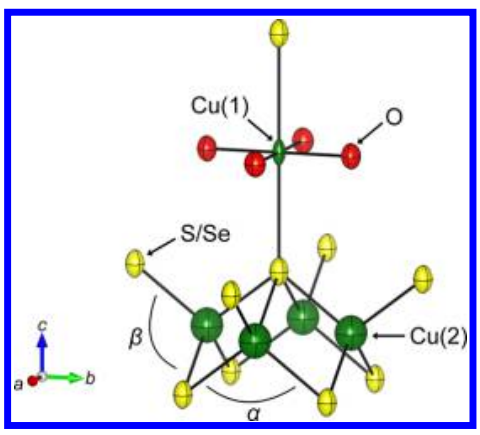

Figure 3. Fragment of the crystal structure of $\mathrm{Sr}_{2} \mathrm{CuO}_{2} \mathrm{Cu}_{2} \mathrm{~S}_{2}$ and $\mathrm{Sr}_{2} \mathrm{CuO}_{2} \mathrm{Cu}_{2} \mathrm{Se}_{2}$, highlighting the coordination environment of both $\mathrm{Cu}$ sites. The anisotropic displacement parameters are those of $\mathrm{Sr}_{2} \mathrm{CuO}_{2} \mathrm{Cu}_{2} \mathrm{Se}_{2}$ shown at $99 \%$ probability, and $\mathrm{Sr}$ atoms have been excluded for clarity. For bond lengths and angles, see Tables 2 and 3.

Table 1. Structural Models for $\mathrm{Sr}_{2} \mathrm{CuO}_{2} \mathrm{Cu}_{2} \mathrm{~S}_{2}$ and $\mathrm{Sr}_{2} \mathrm{CuO}_{2} \mathrm{Cu}_{2} \mathrm{Se}_{2}$ from Rietveld Refinement against PND Data

$\begin{array}{lll}\text { compound } & \mathrm{Sr}_{2} \mathrm{CuO}_{2} \mathrm{Cu}_{2} \mathrm{~S}_{2} & \mathrm{Sr}_{2} \mathrm{CuO}_{2} \mathrm{Cu}_{2} \mathrm{Se}_{2} \\ \text { radiation } & \text { neutron, time of flight } & \\ \text { diffractometer } & \text { POLARIS } & \mathrm{GEM} \\ \text { temperature } & \mathrm{RT} & \\ \text { space group } & \mathrm{I} / \mathrm{mmm}^{a} & \\ \text { impurities } & \mathrm{Cu}(10.8 \mathrm{wt} \%), \mathrm{SrS}(2.6 \mathrm{wt} \%), \mathrm{SrSO}_{4} & \mathrm{Cu}_{2} \mathrm{Se}(0.7 \mathrm{wt} \%) \\ (\text { wt } \%) & (7.4 \mathrm{wt} \%) & \\ a(\AA) & 3.92077(7) & 3.97116(4) \\ c(\AA) & 18.2053(4) & 18.8198(2) \\ \text { volume }\left(\AA^{3}\right) & 279.86(1) & 296.791(7) \\ z(\mathrm{Sr}) & 0.40771(4) & 0.41190(3) \\ z(\mathrm{Ch}) & 0.17089(8) & 0.16838(2) \\ U_{11}(\mathrm{Sr})\left(\AA^{2}\right) & 0.0044(3) & 0.007(2) \\ U_{33}(\mathrm{Sr})\left(\AA^{2}\right) & 0.0065(4) & 0.0086(4) \\ U_{11}(\mathrm{Cu}(1)) & 0.0021(3) & 0.0033(2) \\ \left(\AA^{2}\right) & & \\ U_{33}(\mathrm{Cu}(1)) & 0.0187(6) & 0.0118(5) \\ \left(\AA^{2}\right) & & \\ U_{11}(\mathrm{O})\left(\AA^{2}\right) & 0.0046(5) & 0.0072(4) \\ U_{22}(\mathrm{O})\left(\AA^{2}\right) & 0.0076(5) & 0.0054(4) \\ U_{33}(\mathrm{O})\left(\AA^{2}\right) & 0.0163(6) & 0.0097(6) \\ U_{11}(\mathrm{Cu}(2)) & 0.0121(3) & 0.0151(3) \\ \left(\AA^{2}\right) & & \\ U_{33}(\mathrm{Cu}(2)) & 0.0176(5) & 0.0177(5) \\ \left(\AA^{2}\right) & & \\ U_{11}(\mathrm{Ch})\left(\AA^{2}\right) & 0.0031(8) & 0.0055(3) \\ U_{33}(\mathrm{Ch})\left(\AA^{2}\right) & 0.001(1) & 0.0109(4) \\ R_{\text {wp }}(\%) & 2.200 & 3.683 \\ a_{I 4} / m m m & 4 e(0,0, z(\mathrm{Sr})), \mathrm{Cu}(1): 2 a(0,0,0), & 0 \\ \mathrm{Cu}(2): 4 d(0,1 / 2,1 / 4), \mathrm{Ch}: 4 e(0,0, z(\mathrm{Ch})) . & \\ & & \end{array}$

cryostream on I11). No additional peaks or peak splitting were observed that might have indicated a change in symmetry and the lattice parameters changed smoothly as a function of temperature in these temperature ranges (see Figures S4 and S5 in the Supporting Information).

Our structural characterization of $\mathrm{Sr}_{2} \mathrm{CuO}_{2} \mathrm{Cu}_{2} \mathrm{~S}_{2}$ completes the family of four late-transition metal phases $\mathrm{Sr}_{2} \mathrm{MO}_{2} \mathrm{Cu}_{2} \mathrm{~S}_{2}$ with $\mathrm{M}=\mathrm{Co}, \mathrm{Ni}, \mathrm{Cu}$, and $\mathrm{Zn}$ and enables an analysis of the influence of the electron count on the details of the crystal structure, particularly the shape of the $\mathrm{MO}_{4} \mathrm{~S}_{2}$-distended octahedron. In these oxide chalcogenides, the ligand field about the transition-metal ion is far from octahedral because the $\mathrm{Ch}$ ions in the axial positions have much larger radii than 
Table 2. Comparison of Lattice Parameters and Selected Bond Lengths of $\mathrm{Sr}_{2} \mathrm{CoO}_{2} \mathrm{Cu}_{2} \mathrm{~S}_{2}, \mathrm{Sr}_{2} \mathrm{NiO}_{2} \mathrm{Cu}_{2} \mathrm{~S}_{2}, \mathrm{Sr}_{2} \mathrm{CuO}_{2} \mathrm{Cu}_{2} \mathrm{~S}_{2}$ and $\mathrm{Sr}_{2} \mathrm{ZnO}_{2} \mathrm{Cu}_{2} \mathrm{~S}_{2}$

$\begin{array}{lll}\begin{array}{l}\text { compound } \\ \text { reference }\end{array} & \mathrm{Sr}_{2} \mathrm{CoO}_{2} \mathrm{Cu}_{2} \mathrm{~S}_{2} & \mathrm{Sr}_{2} \mathrm{NiO}_{2} \mathrm{Cu}_{2} \mathrm{~S}_{2} \\ \text { radiation } & \mathrm{ref} 10 & \mathrm{ref} 9 \\ a(\AA) & \mathrm{PND} & \mathrm{PND} \\ c(\AA) & 3.99129(2) & 3.92159(2) \\ c / a & 17.71555(9) & 18.11558(15) \\ \text { volume }\left(\AA^{3}\right) & 4.43855(3) & 4.61945(4) \\ \mathrm{M}-\mathrm{O}(\AA)[4]^{a} & 282.216(3) & 278.597(5) \\ \mathrm{M}-\mathrm{S}(\AA)[2] & 1.99565(1) & 1.96080(1) \\ \mathrm{M}-\mathrm{S} / \mathrm{M}-\mathrm{O} & 3.0327(5) & 3.1054(9) \\ \mathrm{Cu}(2)-\mathrm{S}(\AA)[4] & 1.5197(3) & 1.58374(5) \\ \mathrm{S}-\mathrm{Cu}(2)-\mathrm{S}, \alpha^{b}(\mathrm{deg})[2] & 2.4356(3) & 2.4230(5) \\ \mathrm{S}-\mathrm{Cu}(2)-\mathrm{S}, \beta^{b}(\mathrm{deg})[4] & 109.185(10) & 110.191(15) \\ \end{array}$

$\begin{array}{ll}\mathrm{Sr}_{2} \mathrm{CuO}_{2} \mathrm{Cu}_{2} \mathrm{~S}_{2} & \mathrm{Sr}_{2} \mathrm{ZnO}_{2} \mathrm{Cu}_{2} \mathrm{~S}_{2} \\ \text { this work } & \text { ref } 1 \\ \text { PND } & \text { PXRD } \\ 3.92016(6) & 4.0079(7) \\ 18.2012(4) & 17.720(3) \\ 4.64297(12) & 4.421(1) \\ 279.71(1) & 284.6(1) \\ 1.96008(3) & 2.0040(4) \\ 3.1085(15) & 3.021(4) \\ 1.5859(8) & 1.507(2) \\ 2.4333(9) & 2.450(3) \\ 107.32(6) & 109.31(7) \\ 110.56(3) & 109.79(14)\end{array}$

${ }^{a}$ Numbers in square brackets give the number of bonds or angles of each type. ${ }^{b}$ Angles defined in Figure 3.

Table 3. Comparison of the Lattice Parameters and Bond Lengths of $\mathrm{Sr}_{2} \mathrm{CuO}_{2} \mathrm{Cu}_{2} \mathrm{~S}_{2}, \mathrm{Sr}_{2} \mathrm{CuO}_{2} \mathrm{Cu}_{2} \mathrm{Se}_{2}, \mathrm{Sr}_{2} \mathrm{CuO}_{2} \mathrm{Cl}_{2}$, $\mathrm{Sr}_{2} \mathrm{CuO}_{2} \mathrm{Br}_{2}$, and $\mathrm{Ba}_{2} \mathrm{CuO}_{2} \mathrm{Cu}_{2} \mathrm{Se}_{2}$

\begin{tabular}{|c|c|c|c|c|c|}
\hline $\begin{array}{l}\text { compound } \\
\text { reference }\end{array}$ & $\begin{array}{l}\mathrm{Sr}_{2} \mathrm{CuO}_{2} \mathrm{Cu}_{2} \mathrm{~S}_{2} \\
\text { this work }\end{array}$ & $\begin{array}{l}\mathrm{Sr}_{2} \mathrm{CuO}_{2} \mathrm{Cu}_{2} \mathrm{Se}_{2} \\
\text { this work }\end{array}$ & $\begin{array}{l}\mathrm{Sr}_{2} \mathrm{CuO}_{2} \mathrm{Cl}_{2} \\
\text { ref } 16\end{array}$ & $\begin{array}{l}\mathrm{Sr}_{2} \mathrm{CuO}_{2} \mathrm{Br}_{2} \\
\text { ref } 33\end{array}$ & $\begin{array}{l}\mathrm{Ba}_{2} \mathrm{CuO}_{2} \mathrm{Cu}_{2} \mathrm{Se}_{2} \\
\text { ref } 12\end{array}$ \\
\hline source & PND & PND & PND & $\operatorname{SCXRD}^{a}$ & PND \\
\hline$a(\AA)$ & $3.92016(6)$ & $3.97117(4)$ & $3.9716(2)$ & 3.991 & $4.0885(2)$ \\
\hline$c(\AA)$ & $18.2012(4)$ & $18.8199(2)$ & $15.6126(2)$ & 17.136 & $19.6887(4)$ \\
\hline$c / a$ & $4.64297(12)$ & $4.73913(8)$ & $3.9311(2)$ & 4.294 & $4.8156(3)$ \\
\hline volume $\left(\AA^{3}\right)$ & $279.71(1)$ & $296.792(7)$ & $246.27(3)$ & 272.94 & $329.11(3)$ \\
\hline $\mathrm{Cu}(1)-\mathrm{O}(\AA)[4]^{b}$ & $1.96008(3)$ & $1.98558(2)$ & $1.9858(1)$ & 2.00 & $2.0443(1)$ \\
\hline $\mathrm{Cu}(1)-\mathrm{E}^{c}(\AA)[2]$ & $3.1085(15)$ & $3.1698(4)$ & $2.859(1)$ & 2.98 & $3.4465(12)$ \\
\hline $\mathrm{Cu}(1)-\mathrm{E} / \mathrm{Cu}(1)-\mathrm{O}$ & $1.5859(8)$ & $1.5964(2)$ & $1.4397(5)$ & 1.49 & $1.6859(6)$ \\
\hline $\mathrm{Cu}(2)-\mathrm{Ch}(\AA)[4]$ & $2.4333(9)$ & $2.5098(2)$ & $\mathrm{N} / \mathrm{A}$ & $\mathrm{N} / \mathrm{A}$ & $2.5212(4)$ \\
\hline $\mathrm{Ch}-\mathrm{Cu}(2)-\mathrm{Ch}, \alpha^{d}(\mathrm{deg})[2]$ & $107.32(6)$ & $104.580(15)$ & $\mathrm{N} / \mathrm{A}$ & $\mathrm{N} / \mathrm{A}$ & 108.3 \\
\hline $\mathrm{Ch}-\mathrm{Cu}(2)-\mathrm{Ch}, \beta^{d}(\operatorname{deg})[4]$ & $110.56(3)$ & $111.971(8)$ & $\mathrm{N} / \mathrm{A}$ & $\mathrm{N} / \mathrm{A}$ & 110.0 \\
\hline
\end{tabular}

${ }^{a} \mathrm{SCXRD}=$ single crystal XRD. ${ }^{b}$ Numbers in square brackets give the number of bonds or angles of each type. ${ }^{c} E=$ chalcogenide or halide. ${ }^{d}$ Angles defined in Figure 3.

the oxide ions in the equatorial plane and because of the presence of $\mathrm{Sr}^{2+}$ ions located between the $\mathrm{MO}_{2}$ and $\mathrm{Cu}_{2} \mathrm{Ch}_{2}$ layers: the highly anisotropic ligand field is thus enforced by these two features of the crystal structure. The $\mathrm{M}-\mathrm{S} / \mathrm{M}-\mathrm{O}$ ratio of $1.507(2)$ for $\mathrm{Sr}_{2} \mathrm{ZnO}_{2} \mathrm{Cu}_{2} \mathrm{~S}_{2}$ offers a useful benchmark for the distention of the ligand field enforced by the crystal structure for the case where the transition metal ion is electronically inert $\left(\mathrm{d}^{10}\right)$. The fact that this ratio is much greater than the ratio of $\left[r\left(\mathrm{Zn}^{2+}\right)+r\left(\mathrm{~S}^{2-}\right)\right) /\left(r\left(\mathrm{Zn}^{2+}\right)+\right.$ $\left.r\left(\mathrm{O}^{2-}\right)\right]$ of 1.20 (using ionic radii ${ }^{30}$ for $\mathrm{Zn}^{2+}, \mathrm{S}^{2-}$, and $\mathrm{O}^{2-}$ of $0.74,1.84$ and $1.40 \AA$ ) reflects the effect of incorporating $\mathrm{Sr}^{2+}$ ions between the layers.

When there is no enforcement of distortion by the crystal structure, electronic effects may produce large distortions of octahedral coordination environments. The $\mathrm{e}_{\mathrm{g}}$ orbital degeneracy in an octahedral $\mathrm{d}^{9} \mathrm{Cu}^{2+}$ system (i.e., unequal occupancy of the $\sigma$-antibonding orbitals) drives a strong Jahn-Teller distortion, and the axial/equatorial ratio for $\mathrm{Cu}-\mathrm{Hal}$ bonds in the binary halides $\mathrm{CuCl}_{2}$ and $\mathrm{CuBr}_{2}$ of $1.310(4)^{31}$ and $1.3038(4),{ }^{32}$ respectively, shows the structural impact of the Jahn-Teller effect in $\mathrm{Cu}^{2+}$ systems. Equipped with these benchmarks, we can interpret the trends in the $\mathrm{M}-\mathrm{S} / \mathrm{M}-\mathrm{O}$ ratio across the four structures shown in Table 2. Previous calculations and measurements suggest that the $\mathrm{Co}^{2+}$ ion $\mathrm{Sr}_{2} \mathrm{CoO}_{2} \mathrm{Cu}_{2} \mathrm{~S}_{2}$ has a high-spin $\left(\mathrm{d}_{x z}\right)^{2}\left(\mathrm{~d}_{y z}\right)^{2}\left(\mathrm{~d}_{x y}\right)^{1}\left(\mathrm{~d}_{z}^{2}\right)^{1}\left(\mathrm{~d}_{x^{2}-y^{2}}\right)^{1}$ configuration, ${ }^{10}$ and the $\mathrm{Co}-\mathrm{S} / \mathrm{Co}-\mathrm{O}$ ratio of $1.5197(2)$, which is very similar to that for $\mathrm{Sr}_{2} \mathrm{ZnO}_{2} \mathrm{Cu}_{2} \mathrm{~S}_{2}$, is entirely consistent with the equal occupancy of the $\sigma$-antibonding $\mathrm{d}$ orbitals in the case of high spin $\mathrm{d}^{7} \mathrm{Co}^{2+}$. In contrast, the $\left(\mathrm{d}_{x z}\right)^{2}\left(\mathrm{~d}_{y z}\right)^{2}\left(\mathrm{~d}_{x y}\right)^{2}\left(\mathrm{~d}_{z}^{2}\right)^{2}\left(\mathrm{~d}_{x^{2}-y^{2}}\right)^{1}$ configuration for $\mathrm{Cu}^{2+}$ in $\mathrm{Sr}_{2} \mathrm{CuO}_{2} \mathrm{Cu}_{2} \mathrm{~S}_{2}$ with unequal occupancy of the $\sigma$-antibonding $\mathrm{d}$ orbitals (i.e., the driver for a Jahn-Teller distortion of octahedral $\mathrm{Cu}^{2+}$ ) should drive a further axial distension, and the data reported here for $\mathrm{Sr}_{2} \mathrm{CuO}_{2} \mathrm{Cu}_{2} \mathrm{~S}_{2}$ show that the $\mathrm{Cu}-\mathrm{S}$ / $\mathrm{Cu}-\mathrm{O}$ ratio increases to $1.5859(8)$, confirming that there is indeed an additional electronic effect controlling the anisotropy of the $\mathrm{CuO}_{4} \mathrm{~S}_{2}$ ligand field. The increase in the $\mathrm{M}-\mathrm{S} / \mathrm{M}-\mathrm{O}$ ratio from $1.507(2)$ for $\mathrm{Zn}$ to $1.5859(8)$ for $\mathrm{Cu}$ is, however, rather smaller than it might have been expected based on the axial/equatorial ratio of $\sim 1.3$, resulting from the Jahn-Teller distortion in the copper halides. The apparently diminished influence of the electronic configuration probably reflects the effect of accommodating $\mathrm{Sr}^{2+}$ ions in the structure, which imposes unnaturally long $\mathrm{M}-\mathrm{S}$ bond lengths (i.e., in the extreme limit that the overlap of orbitals on $M$ and $S$ is negligible, the $\mathrm{M}-\mathrm{S}$ bond lengths should be independent of the occupation of the $\mathrm{d}_{z}{ }^{2}$ orbital). We note here that the M-S/ $\mathrm{M}-\mathrm{O}$ ratio of $1.58374(5)$ for $\mathrm{Sr}_{2} \mathrm{NiO}_{2} \mathrm{Cu}_{2} \mathrm{~S}_{2}{ }^{9}$ appears to be surprisingly large: a $\left(\mathrm{d}_{x z}\right)^{2}\left(\mathrm{~d}_{y z}\right)^{2}\left(\mathrm{~d}_{x y}\right)^{2}\left(\mathrm{~d}_{z}^{2}\right)^{1}\left(\mathrm{~d}_{x^{2}-y^{2}}\right)^{1}$ configuration with equal populations of the $\sigma$-antibonding orbitals (i.e., octahedral $\mathrm{d}^{8} \mathrm{Ni}^{2+}$ is not Jahn-Teller-active) would suggest a $\mathrm{Ni}-\mathrm{S} / \mathrm{Ni}-\mathrm{O}$ ratio similar to that found for the Co and $\mathrm{Zn}$ analogues (around 1.50). Previously, ${ }^{10}$ we have noted that the very long $\mathrm{M}-\mathrm{S}$ bonds cause the ligand field to become more 
square planar, and indeed in the extreme limit, the $d_{z}{ }^{2}$ orbital can drop below $\mathrm{d}_{x y}$. This would give a $\left(\mathrm{d}_{x z}\right)^{2}\left(\mathrm{~d}_{y z}\right)^{2}\left(\mathrm{~d}_{z}^{2}\right)^{2}\left(\mathrm{~d}_{x y}\right)^{1}\left(\mathrm{~d}_{x^{2}-y^{2}}\right)^{1}$ configuration for $\mathrm{Sr}_{2} \mathrm{NiO}_{2} \mathrm{Cu}_{2} \mathrm{~S}_{2}$, which would account for a large $\mathrm{M}-\mathrm{S} / \mathrm{M}-\mathrm{O}$ ratio similar to that in $\mathrm{Sr}_{2} \mathrm{CuO}_{2} \mathrm{Cu}_{2} \mathrm{~S}_{2}$ (the two compounds would have similar populations of the $\sigma$-antibonding $\mathrm{d}$ orbitals). However, we have previously noted in ref 9 that there is some ambiguity about the nature of the spin state and configuration in $\mathrm{Sr}_{2} \mathrm{NiO}_{2} \mathrm{Cu}_{2} \mathrm{~S}_{2}$ that requires further investigation.

In $\mathrm{Sr}_{2} \mathrm{CuO}_{2} \mathrm{Cu}_{2} \mathrm{Ch}_{2}$, substitution of the sulfide ion by the larger selenide leads to only a marginal increase in the $\mathrm{M}-\mathrm{Ch} /$ $\mathrm{M}-\mathrm{O}$ bond length ratio: $1.5859(8)$ for $\mathrm{Sr}_{2} \mathrm{CuO}_{2} \mathrm{Cu}_{2} \mathrm{~S}_{2}$ versus 1.5964(2) for $\mathrm{Sr}_{2} \mathrm{CuO}_{2} \mathrm{Cu}_{2} \mathrm{Se}_{2}$ (Table 3). The change is also small for the Co analogues ${ }^{10,14}$ (see Table S4 in the Supporting Information). This is likely because accommodating the larger selenide ion inevitably increases the $a$ lattice parameter (i.e., the $\mathrm{M}-\mathrm{O}$ distance) and makes the $\mathrm{Sr}^{2+}$ ion accommodation between the oxide and chalcogenide layers possible without forcing the chalcogenide away from the metal cation so much. In contrast, a comparison of $\mathrm{Sr}_{2} \mathrm{CuO}_{2} \mathrm{Cu}_{2} \mathrm{Se}_{2}$ with $\mathrm{Ba}_{2} \mathrm{CuO}_{2} \mathrm{Cu}_{2} \mathrm{Se}_{2}{ }^{12}$ shows that alkaline earth metal substitution has a much greater effect on the $\mathrm{M}-\mathrm{Ch} / \mathrm{M}-\mathrm{O}$ ratio as reported also for the pairs $\mathrm{Sr}_{2} \mathrm{CoO}_{2} \mathrm{Cu}_{2} \mathrm{~S}_{2}$ and $\mathrm{Ba}_{2} \mathrm{CoO}_{2} \mathrm{Cu}_{2} \mathrm{~S}_{2},{ }^{10}$ and $\mathrm{Sr}_{2} \mathrm{CoO}_{2} \mathrm{Ag}_{2} \mathrm{Se}_{2}$ and $\mathrm{Ba}_{2} \mathrm{CoO}_{2} \mathrm{Ag}_{2} \mathrm{Se}_{2}{ }^{11}$ Finally, we draw a comparison between the coordination environment of $\mathrm{Cu}(1)$ in the oxide layer in the oxide chalcogenides $\mathrm{Sr}_{2} \mathrm{CuO}_{2} \mathrm{Cu}_{2} \mathrm{~S}_{2}$ and $\mathrm{Sr}_{2} \mathrm{CuO}_{2} \mathrm{Cu}_{2} \mathrm{Se}_{2}$ with those in $\mathrm{Sr}_{2} \mathrm{CuO}_{2} \mathrm{Cl}_{2}{ }^{16}$ and $\mathrm{Sr}_{2} \mathrm{CuO}_{2} \mathrm{Br}_{2}{ }^{33}$ (see Table 3). The only substantial difference between the structures of these compounds is that the tetrahedral sites between adjacent layers of halide ions are not occupied by metal cations, as they are in the oxide chalcogenides $\mathrm{Sr}_{2} \mathrm{CuO}_{2} \mathrm{Cu}_{2} \mathrm{~S}_{2}$ and $\mathrm{Sr}_{2} \mathrm{CuO}_{2} \mathrm{Cu}_{2} \mathrm{Se}_{2} . \mathrm{Sr}_{2} \mathrm{CuO}_{2} \mathrm{Cl}_{2}$ and $\mathrm{Sr}_{2} \mathrm{CuO}_{2} \mathrm{Br}_{2}$ have longer $\mathrm{Cu}-\mathrm{O}$ distances than $\mathrm{Sr}_{2} \mathrm{CuO}_{2} \mathrm{Cu}_{2} \mathrm{~S}_{2}$ and $\mathrm{Sr}_{2} \mathrm{CuO}_{2} \mathrm{Cu}_{2} \mathrm{Se}_{2}$, respectively. This and the lack of competition for the halide from an ion in the tetrahedral sites between adjacent layers of halide ions mean that for anions of the same period, the $\mathrm{Cu}-$ Hal distances in the oxide halides are substantially shorter than the $\mathrm{Cu}-\mathrm{Ch}$ distances in the oxide chalcogenides and are more affected by the intrinsic size of the halides: the $\mathrm{Cu}-\mathrm{Hal} / \mathrm{Cu}-$ $\mathrm{O}$ ratios in $\mathrm{Sr}_{2} \mathrm{CuO}_{2} \mathrm{Cl}_{2}{ }^{16}$ and $\mathrm{Sr}_{2} \mathrm{CuO}_{2} \mathrm{Br}_{2}{ }^{33}$ are now substantially different, $1.4397(5)$ versus 1.49 , compared to the $\mathrm{Cu}-\mathrm{Ch} / \mathrm{Cu}-\mathrm{O}$ ratios of $1.5859(8)$ and 1.5964(2) for $\mathrm{Sr}_{2} \mathrm{CuO}_{2} \mathrm{Cu}_{2} \mathrm{~S}_{2}$ and $\mathrm{Sr}_{2} \mathrm{CuO}_{2} \mathrm{Cu}_{2} \mathrm{Se}_{2}$, respectively.

Magnetometry. Magnetization isotherms at $300 \mathrm{~K}$ (Figure 4) revealed that samples of $\mathrm{Sr}_{2} \mathrm{CuO}_{2} \mathrm{Cu}_{2} \mathrm{~S}_{2}$ and $\mathrm{Sr}_{2} \mathrm{CuO}_{2} \mathrm{Cu}_{2} \mathrm{Se}_{2}$ both contain small quantities of impurities that were ferromagnetic at RT-possibly adventitious iron at levels of 0.02 and $0.01 \mathrm{~mol} \%$, respectively. Above the saturation field of these impurities, the measurements showed that while $\mathrm{Sr}_{2} \mathrm{CuO}_{2} \mathrm{Cu}_{2} \mathrm{~S}_{2}$ is a net paramagnet, $\mathrm{Sr}_{2} \mathrm{CuO}_{2} \mathrm{Cu}_{2} \mathrm{Se}_{2}$ is a net diamagnet, with a negative magnetic susceptibility in the highfield region of the $300 \mathrm{~K}$ magnetization isotherm. For both samples, two sets of measurements were performed as a function of temperature. Low-field (100 Oe) measurements (Figure S6 in the Supporting Information) confirmed that neither compound exhibited superconductivity above $5 \mathrm{~K}$, while high-field measurements (above the saturation field of the ferromagnetic impurity, as outlined in the experimental and shown in Figure 4) were used to measure the intrinsic magnetic susceptibility of the compounds with the effects of the ferromagnetic impurity subtracted out. These were then

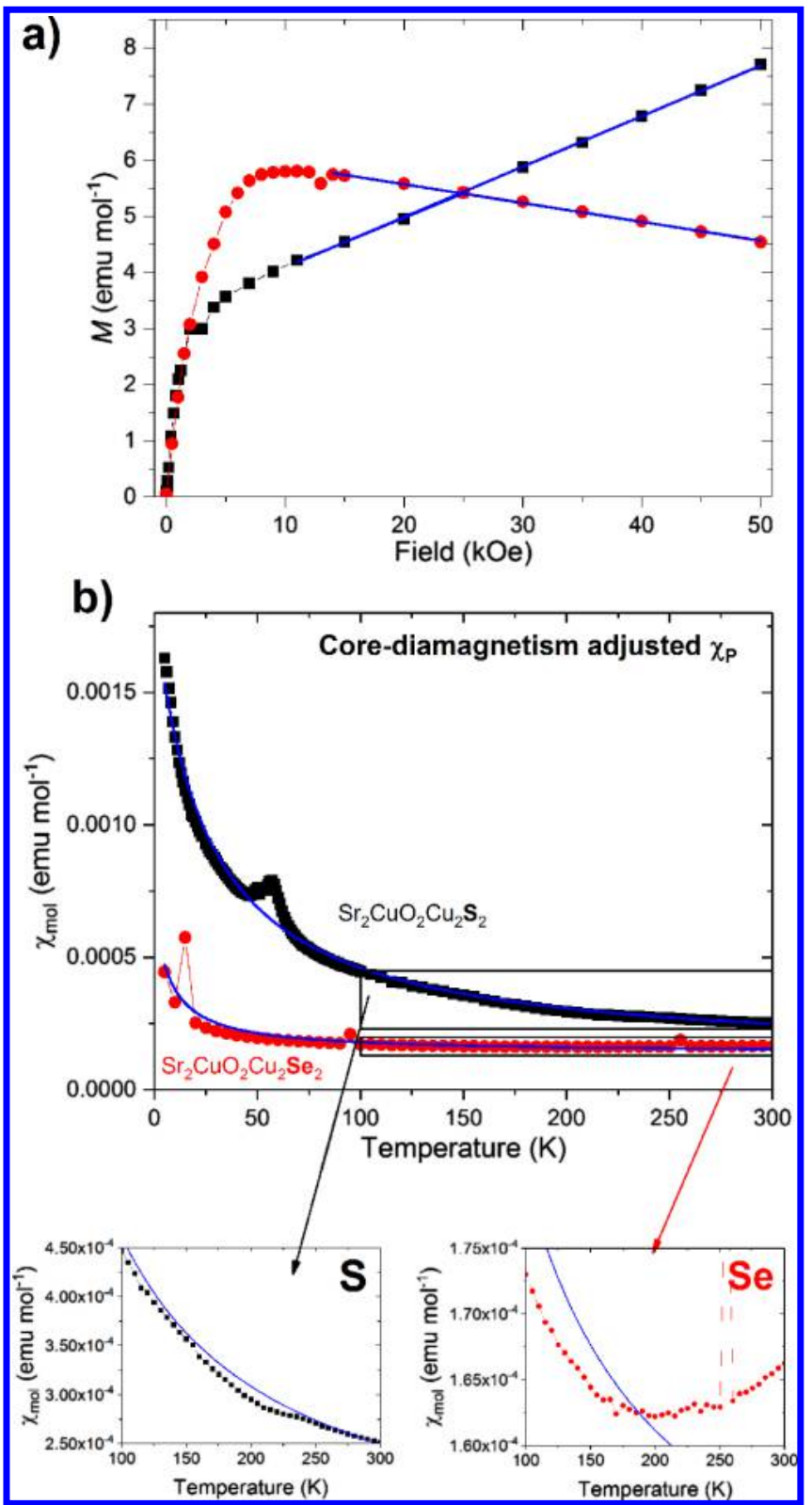

Figure 4. Comparison of the magnetic susceptibility of $\mathrm{Sr}_{2} \mathrm{CuO}_{2} \mathrm{Cu}_{2} \mathrm{~S}_{2}$ and $\mathrm{Sr}_{2} \mathrm{CuO}_{2} \mathrm{Cu}_{2} \mathrm{Se}_{2}$ : (a) comparison of the $\mathrm{RT}$ magnetization isotherms of the two compounds-lines are guides to the eye; (b) comparison of the magnetic susceptibilities as a function of temperature $(5-300 \mathrm{~K})$. A high-field subtraction was performed for both these measurements as described in the Experimental Section, and the (temperature-independent) contribution from core diamagnetism was subtracted. The blue line shows the attempted fit to the equation $\chi=\chi_{0}+C /(T-\theta)$, described in the text. The insets highlight the poor quality of the fit to this equation in the hightemperature region, particularly for $\mathrm{Sr}_{2} \mathrm{CuO}_{2} \mathrm{Cu}_{2} \mathrm{Se}_{2}$.

corrected for the diamagnetism of the core electrons ${ }^{34}$ (see Table S5), and the results are plotted in Figure $4 \mathrm{~b}$. The small feature in the susceptibility of $\mathrm{Sr}_{2} \mathrm{CuO}_{2} \mathrm{Cu}_{2} \mathrm{~S}_{2}$ at $\sim 60 \mathrm{~K}$ is thought to arise from a small amount of $\mathrm{O}_{2}$ contamination in the magnetometer. ${ }^{35}$ As noted above, we found no evidence for any structural anomaly in the $\mathrm{Sr}_{2} \mathrm{CuO}_{2} \mathrm{Cu}_{2} \mathrm{~S}_{2}$ phase at this temperature.

Both compounds are net paramagnets but attempts to fit the susceptibility $(\chi)$ using both Curie-Weiss and temperatureindependent terms $\left(\chi_{0}\right)\left(\chi=\chi_{0}+C /(T-\theta)\right.$, where $C$ is the 
Curie constant and $\theta$ is the Weiss constant) proved incapable of accounting for the high temperature data, as shown in Figure $4 \mathrm{~b}$. The magnetic susceptibility of $\mathrm{Sr}_{2} \mathrm{CuO}_{2} \mathrm{Cu}_{2} \mathrm{Se}_{2}$ decreases from RT down to $200 \mathrm{~K}$, a feature that is often indicative of antiferromagnetic ordering in layered systems. ${ }^{36}$ If so, it should be preceded by a broad susceptibility maximum at higher temperatures, but our apparatus did not allow us to make noise-free measurements significantly above RT. The magnetic susceptibility of the pure compound $\mathrm{Sr}_{2} \mathrm{CuO}_{2} \mathrm{Cu}_{2} \mathrm{Se}_{2}$ is qualitatively and quantitatively similar to that reported by Vaknin et al. ${ }^{36}$ for $\mathrm{Sr}_{2} \mathrm{CuO}_{2} \mathrm{Cl}_{2}$. In contrast, $\mathrm{Li}$ et al. report almost pure Curie type paramagnetism below $250 \mathrm{~K}$ in their sample of $\mathrm{Ba}_{2} \mathrm{CuO}_{2} \mathrm{Cu}_{2} \mathrm{Se}_{2}$, ${ }^{12}$ with a low temperature susceptibility two orders of magnitude larger than we find for $\mathrm{Sr}_{2} \mathrm{CuO}_{2} \mathrm{Cu}_{2} \mathrm{Se}_{2}$. The magnetic susceptibility of $\mathrm{Sr}_{2} \mathrm{CuO}_{2} \mathrm{Cu}_{2} \mathrm{~S}_{2}$ is not easy to interpret, given the known presence of impurities, but it has a distinct feature at $\sim 225 \mathrm{~K}$, which may be indicative of a magnetic ordering transition.

Magnetic Ordering. Low-temperature PND was performed on the pure sample of $\mathrm{Sr}_{2} \mathrm{CuO}_{2} \mathrm{Cu}_{2} \mathrm{Se}_{2}$ to establish whether any additional Bragg peaks appeared on cooling that might indicate antiferromagnetic ordering and also whether there is any distortion of the crystal structure at low temperatures. A $2 \mathrm{~g}$ sample of $\mathrm{Sr}_{2} \mathrm{CuO}_{2} \mathrm{Cu}_{2} \mathrm{Se}_{2}$ was measured using the WISH instrument, where the design of the diffractometer ${ }^{21}$ allows for high resolution extending to very long $d$-spacings and an excellent signal/noise ratio across the whole diffractogram. Measurements were repeated at $1.7 \mathrm{~K}$ and at RT, and no distortion of the crystal structure was evident, similar to the case of $\mathrm{Sr}_{2} \mathrm{CuO}_{2} \mathrm{Cl}_{2}{ }^{16}$ We were, however, able to discern a few low-intensity peaks at long $d$-spacings in the diffraction pattern at $1.7 \mathrm{~K}$ that were not present at RT. These peaks could be indexed using a $\sqrt{ } 2 a \times \sqrt{2 a} \times 2 c$ expansion of the nuclear cell, from which it was concluded that they were magnetic in origin. A symmetry-mode analysis ${ }^{37}$ based on the assumption that the only magnetically ordered ions in the compound were the $\mathrm{Cu}^{2+}$ ions in the $\mathrm{CuO}_{2}$ planes $(\mathrm{Cu}(1))$ revealed that activation of only two magnetic symmetry mode distortions, $\mathrm{mP} 4$ and $\mathrm{mP5}$, led to nonzero intensity at the position of the identified magnetic peaks. Both modes correspond to nearest-neighbor antiferromagnetic interactions in the $a b$ plane with a periodicity of $2 c_{\text {nucl }}$ along the $c$-axis perpendicular to the $\mathrm{CuO}_{2}$ planes. The $\mathrm{mP} 4$ mode has the moments orientated in the $c$-direction, whereas $\mathrm{mP5}$ has them orientated in the $a b$ plane. The extremely low intensity of the magnetic peaks relative to the nuclear Bragg peaks made it difficult to distinguish the two magnetic models, but the model with the $\mathrm{mP5}$ mode activated gave a marginally better agreement factor and a better visual fit to the magnetic intensity distribution (see the Supporting Information Figures S7-S10). The highest symmetry magnetic space group that could accommodate both the MP5 symmetry mode and the tetragonal crystal symmetry was $I_{c}-42 d$ (122.338 using the Belov-Neronova-Smirnova scheme ${ }^{38}$ and $P_{I^{-}} 4 n 2$ (118.6.970) using the Opechowski-Guccione scheme). ${ }^{39}$ The corresponding Rietveld refinement is shown in Figure 5. The refined magnetic moment per $\mathrm{Cu}^{2+}$ ion in the oxide layer was $0.39(6)$ $\mu_{\mathrm{B}}$, similar within experimental uncertainty to the values of $0.34 \pm 0.04$ and $0.35 \pm 0.05 \mu_{\mathrm{B}}$ per $\mathrm{Cu}$ ion reported for $\mathrm{Sr}_{2} \mathrm{CuO}_{2} \mathrm{Cl}_{2}{ }^{36}$ and $\mathrm{La}_{2} \mathrm{CuO}_{4}{ }^{40}$ respectively. In all cases, the ordered moments are significantly reduced below the spin-only value (1.0) by covalency and quantum fluctuations. Our magnetic model for $\mathrm{Sr}_{2} \mathrm{CuO}_{2} \mathrm{Cu}_{2} \mathrm{Se}_{2}$ is similar to that proposed

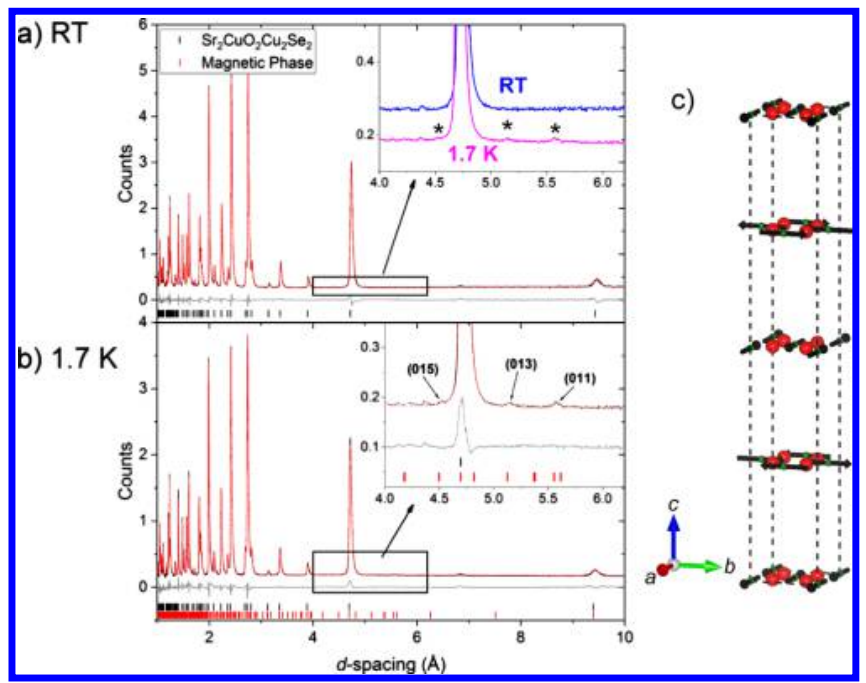

Figure 5. Rietveld plot of the PND pattern of $\mathrm{Sr}_{2} \mathrm{CuO}_{2} \mathrm{Cu}_{2} \mathrm{Se}_{2}$ measured using the $2-9\left(2 \theta=58.3^{\circ}\right)$ bank of WISH at (a) RT and (b) $1.7 \mathrm{~K}$ (Table S10). The inset in (a) highlights the peaks present at $1.7 \mathrm{~K}$ that are not observed at RT, whereas the inset in (b) highlights the fit of these peaks (indexed using the expanded magnetic unit cell). (c) shows the magnetic structure found from Rietveld refinement against these reflections. The small additional reflections at $d \approx 4.35$ and $6.85 \AA$ which are invariant with temperature are presumed to be due to small amounts of unidentified impurities.

by Vaknin et al. ${ }^{36}$ for $\mathrm{Sr}_{2} \mathrm{CuO}_{2} \mathrm{Cl}_{2}$ : both have the spins aligned in the $a b$ plane, and the strongest interactions involve antiferromagnetic superexchange couplings via $180^{\circ} \mathrm{Cu}-\mathrm{O}-$ $\mathrm{Cu}$ linkages. The two magnetic models differ in their periodicity along the $c$ direction with moments related by the lattice vector $c$ arranged parallel in $\mathrm{Sr}_{2} \mathrm{CuO}_{2} \mathrm{Cl}_{2}{ }^{36}$ but antiparallel in $\mathrm{Sr}_{2} \mathrm{CuO}_{2} \mathrm{Cu}_{2} \mathrm{Se}_{2}$.

In contrast to the data on $\mathrm{Sr}_{2} \mathrm{CuO}_{2} \mathrm{Cu}_{2} \mathrm{Se}_{2}$, no additional peaks were observed in the low-temperature $(2 \mathrm{~K})$ neutron diffraction pattern of the impure $\mathrm{Sr}_{2} \mathrm{CuO}_{2} \mathrm{Cu}_{2} \mathrm{~S}_{2}$ sample at a similar range of $d$-spacings (see Figure $\mathrm{S} 11$ in the Supporting Information). We note, however, that this sample was measured on the POLARIS diffractometer rather than WISH, and the former is better optimized for measurements at short $d$-spacings. Therefore, even if $\mathrm{Sr}_{2} \mathrm{CuO}_{2} \mathrm{Cu}_{2} \mathrm{~S}_{2}$ were to display magnetic scattering of a similar intensity to the selenide analogue, the peaks would not be expected to appear above the noise level of the measurement. We cannot, therefore, rule out the possibility that $\mathrm{Sr}_{2} \mathrm{CuO}_{2} \mathrm{Cu}_{2} \mathrm{~S}_{2}$ is also magnetically ordered with a similar (small) magnetic moment at $\mathrm{Cu}(1)$ to that in the selenide; further measurements on a purer sample would be required to resolve this issue. We also note that $\mathrm{Li}$ et al. ${ }^{12}$ found no evidence for magnetic scattering from their comparison of neutron diffractograms for $\mathrm{Ba}_{2} \mathrm{CuO}_{2} \mathrm{Cu}_{2} \mathrm{Se}_{2}$ at $\mathrm{RT}$ and $3 \mathrm{~K}$, measured on a constant wavelength diffractometer. However, given the noise level shown in their data, it is not clear whether the weak magnetic peaks arising from small localized moments such as those found for $\mathrm{Sr}_{2} \mathrm{CuO}_{2} \mathrm{Cu}_{2} \mathrm{Se}_{2}$ or $\mathrm{Sr}_{2} \mathrm{CuO}_{2} \mathrm{Cl}_{2}$ would be evident. We cannot, therefore, rule out the possibility that small localized moments are present in $\mathrm{Cu}(1)$ in either or both of $\mathrm{Ba}_{2} \mathrm{CuO}_{2} \mathrm{Cu}_{2} \mathrm{Se}_{2}$ and $\mathrm{Sr}_{2} \mathrm{CuO}_{2} \mathrm{Cu}_{2} \mathrm{~S}_{2}$.

Resistivity Measurements. The resistivity of $\mathrm{Sr}_{2} \mathrm{CuO}_{2} \mathrm{Cu}_{2} \mathrm{Se}_{2}$ was measured using a pellet sintered at the synthesis temperature $\left(500{ }^{\circ} \mathrm{C}\right)$, as described in the Experimental Section, both on cooling and on warming: the 
two measurements were reproducible within the experimental uncertainty (Figure 6a). The RT resistivity of $0.34 \Omega \mathrm{cm}$ is

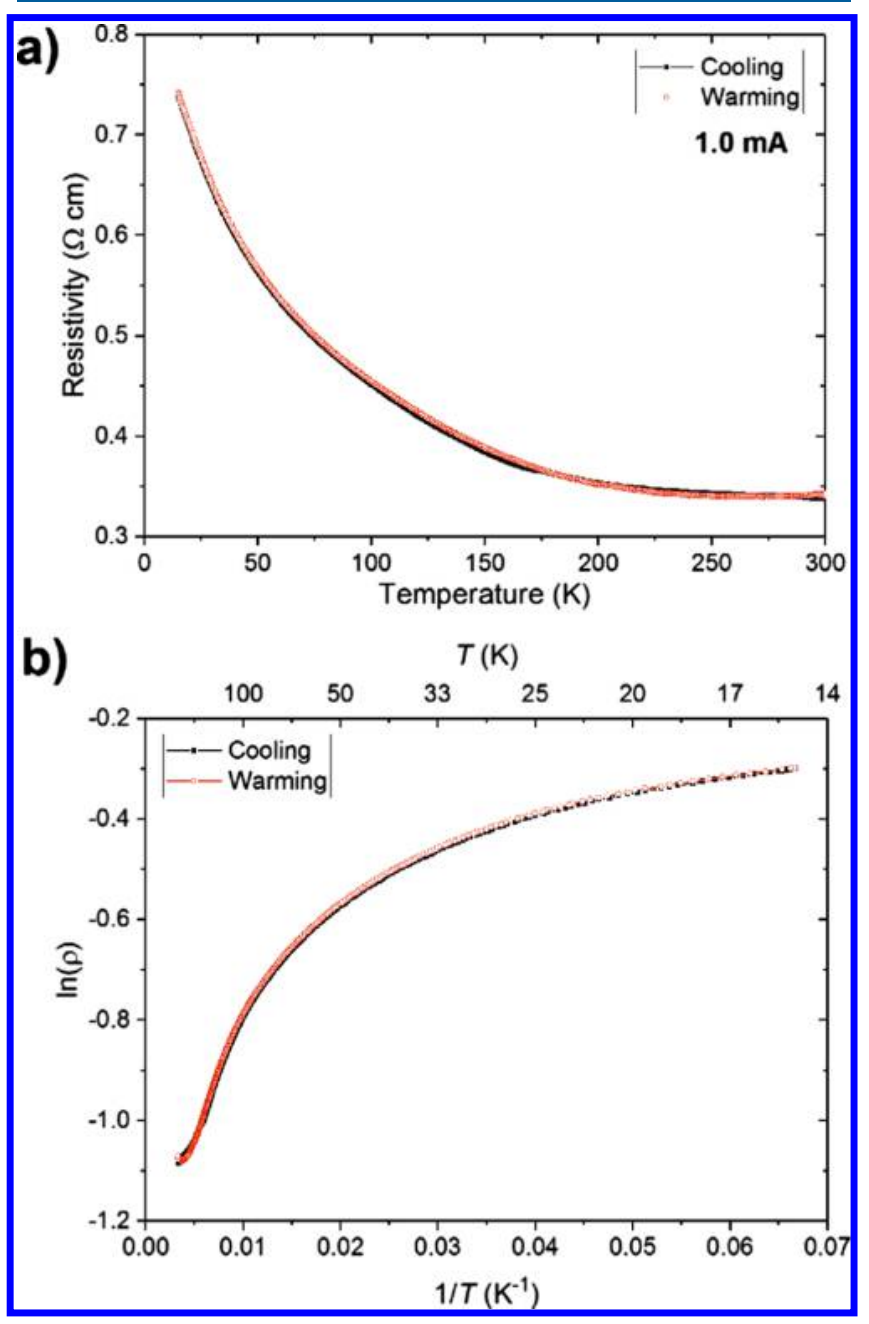

Figure 6. (a) Bulk resistivity of $\mathrm{Sr}_{2} \mathrm{CuO}_{2} \mathrm{Cu}_{2} \mathrm{Se}_{2}$ as a function of temperature, measured with a constant current of $1.0 \mathrm{~mA}$ and (b) a plot of $\ln (\rho)$ vs $1 / T$.

almost one order of magnitude larger than that reported for $\mathrm{Ba}_{2} \mathrm{CuO}_{2} \mathrm{Cu}_{2} \mathrm{Se}_{2}$, ${ }^{12}$ although the values measured for the two compounds are more similar at $10 \mathrm{~K}(0.7 \Omega \mathrm{cm})$, and the temperature dependences are qualitatively comparable. A plot of $\ln (\rho)$ versus $1 / T$ is nonlinear over the whole temperature range (Figure $6 \mathrm{~b}$ ), complicating attempts to extract a value for the band gap. The resistivity measured for the powder sample of $\mathrm{Sr}_{2} \mathrm{CuO}_{2} \mathrm{Cu}_{2} \mathrm{Se}_{2}$ at $\mathrm{RT}$ is, however, approximately 6 orders of magnitude smaller than that obtained from single crystal measurements on $\mathrm{Sr}_{2} \mathrm{CuO}_{2} \mathrm{Cl}_{2},{ }^{16}$ and we discuss a possible reason for this below. We were unable to measure the resistivity of $\mathrm{Sr}_{2} \mathrm{CuO}_{2} \mathrm{Cu}_{2} \mathrm{~S}_{2}$ because the powder sample was too impure (in particular, the sample contained large quantities of elemental copper).

Electronic Structure Analysis. In order to explore the electronic structure of both the oxide sulfide and oxide selenide phases, we carried out a series of density functional calculations for $\mathrm{Sr}_{2} \mathrm{CuO}_{2} \mathrm{Cu}_{2} \mathrm{~S}_{2}$ and $\mathrm{Sr}_{2} \mathrm{CuO}_{2} \mathrm{Cu}_{2} \mathrm{Se}_{2}$ using a plane-wave basis, as implemented in the VASP software package. ${ }^{23} \mathrm{~A} \sqrt{ } 2 a$ $\times \sqrt{2 a} \times c$ basal plane expansion of the tetragonal nuclear unit cell was used so that the magnetic coupling between $\mathrm{Cu}^{2+}$ ions in the $\mathrm{CuO}_{2}$ planes could be addressed (subsequent tests using the larger $\sqrt{ } 2 a \times \sqrt{ } 2 a \times 2 c$ expansion observed experimentally for $\mathrm{Sr}_{2} \mathrm{CuO}_{2} \mathrm{Cu}_{2} \mathrm{Se}_{2}$ confirmed that the interplane coupling is very weak, and the calculated in-plane magnetic ordering is unaffected). In both $\mathrm{Sr}_{2} \mathrm{CuO}_{2} \mathrm{Cu}_{2} \mathrm{~S}_{2}$ and $\mathrm{Sr}_{2} \mathrm{CuO}_{2} \mathrm{Cu}_{2} \mathrm{Se}_{2}$, our calculations indicate an antiferromagnetic ground state with optimized lattice parameters and bond lengths that are very close to the experimental values (Table 4). In the case of $\mathrm{Sr}_{2} \mathrm{CuO}_{2} \mathrm{Cu}_{2} \mathrm{~S}_{2}$, the close agreement between calculated and experimental parameters increases our confidence in the data collected from an impure sample. The spinpolarized DOS for the AF ground state of $\mathrm{Sr}_{2} \mathrm{CuO}_{2} \mathrm{Cu}_{2} \mathrm{Se}_{2}$ is shown in Figure 7, along with the band structure along a path through the high-symmetry points of the tetragonal Brillouin zone. The computed band structure and DOS for $\mathrm{Sr}_{2} \mathrm{CuO}_{2} \mathrm{Cu}_{2} \mathrm{Se}_{2}$ are very similar to those reported by $\mathrm{Li}$ et al. for the $\mathrm{Ba}$ analogue, ${ }^{12}$ with a vacant minority-spin $\mathrm{Cu} \mathrm{d}_{x^{2}-y^{2}}$ band lying just above the Fermi level. The remaining $\mathrm{Cu}^{2+} 3 \mathrm{~d}$ bands (dark green) are all fully occupied and are located 4.5-7.5 eV below the Fermi level. The $\mathrm{Cu} \mathrm{d} x_{x-y^{2}}$ band is strongly dispersed in the $a b$ plane $(\Gamma \rightarrow X \rightarrow M$ and $Z \rightarrow R \rightarrow$ $A)$ but not along $c(\Gamma \rightarrow Z, X \rightarrow R, M \rightarrow A)$, and it approaches the Fermi level in the vicinity of $M$ and $A$. Just below the Fermi level, the DOS is dominated by Se $4 p$ states (yellow), with the $\mathrm{O} 2 \mathrm{p}$ band (red) lying approximately $2 \mathrm{eV}$ lower. The calculated local moment on the $\mathrm{Cu}(1) \mathrm{Cu}^{2+}$ site of $0.68 \mu_{\mathrm{B}}$ is comparable to the value of $0.39(6) \mu_{\mathrm{B}}$ obtained from fitting the low-temperature neutron diffraction data, particularly given the large uncertainty in the latter. We also note that the precise magnitude of the calculated moment is highly sensitive to the

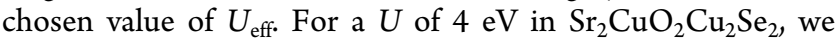
calculate a smaller moment of $0.51 \mu_{\mathrm{B}}$, and this also leads to the changes in the details of the band structure discussed below and shown in Figure S13.

The electronic structure of the analogous sulfide $\mathrm{Sr}_{2} \mathrm{CuO}_{2} \mathrm{Cu}_{2} \mathrm{~S}_{2}$, Figure $\mathrm{S} 12$, is almost indistinguishable from that of the selenide, and the calculated local moment at $\mathrm{Cu}^{2+}$ of $0.68 \mu_{\mathrm{B}}$ is identical in the two compounds. As described above, we were unable to discern any low-intensity magnetic Bragg peaks above the background for $\mathrm{Sr}_{2} \mathrm{CuO}_{2} \mathrm{Cu}_{2} \mathrm{~S}_{2}$, but the similarities in the structure and calculated DOS suggest that an ordered moment should be present in this case too. The DOS

Table 4. Optimized Lattice Parameters, $a$ and $c, \mathrm{Cu}^{2+}-\mathrm{O}$ and $\mathrm{Cu}^{2+}-\mathrm{Ch}$ Bond Lengths and Spin Densities on $\mathrm{Cu}^{2+}$ in $\mathrm{Sr}_{2} \mathrm{CuO}_{2} \mathrm{Cu}_{2} \mathrm{~S}_{2}, \mathrm{Sr}_{2} \mathrm{CuO}_{2} \mathrm{Cu}_{2} \mathrm{Se}_{2}$, and $\mathrm{Ba}_{2} \mathrm{CuO}_{2} \mathrm{Cu}_{2} \mathrm{Se}_{2}{ }^{a}$

$\begin{array}{ccccccc} & & \left|\mu\left(\mathrm{Cu}^{2+}\right)\right|(\mu \mathrm{B}) & \mathrm{Cu}^{2+}-\mathrm{O}(\AA) & \mathrm{Cu}^{2+}-\mathrm{Ch}(\AA) & a(\AA) & c(\AA) \\ \mathrm{Sr}_{2} \mathrm{CuO}_{2} \mathrm{Cu}_{2} \mathrm{Se}_{2} & \text { axp. } & 0.39(6) & 1.99 & 3.17 & 3.97 & 18.82 \\ & \text { calc. } & 0.68 & 2.00 & 3.17 & 3.99 & 18.75 \\ \mathrm{Sr}_{2} \mathrm{CuO}_{2} \mathrm{Cu}_{2} \mathrm{~S}_{2} & \text { exp. } & & 1.96 & 3.11 & 3.92 & 18.20 \\ & \text { calc. } & 0.68 & 1.96 & 3.13 & 3.93 & 18.09\end{array}$

${ }^{a}$ All reported values are obtained with a Hubbard $U_{\text {eff }}$ value of $7.0 \mathrm{eV}$ on $\mathrm{Cu}^{2+}$. 


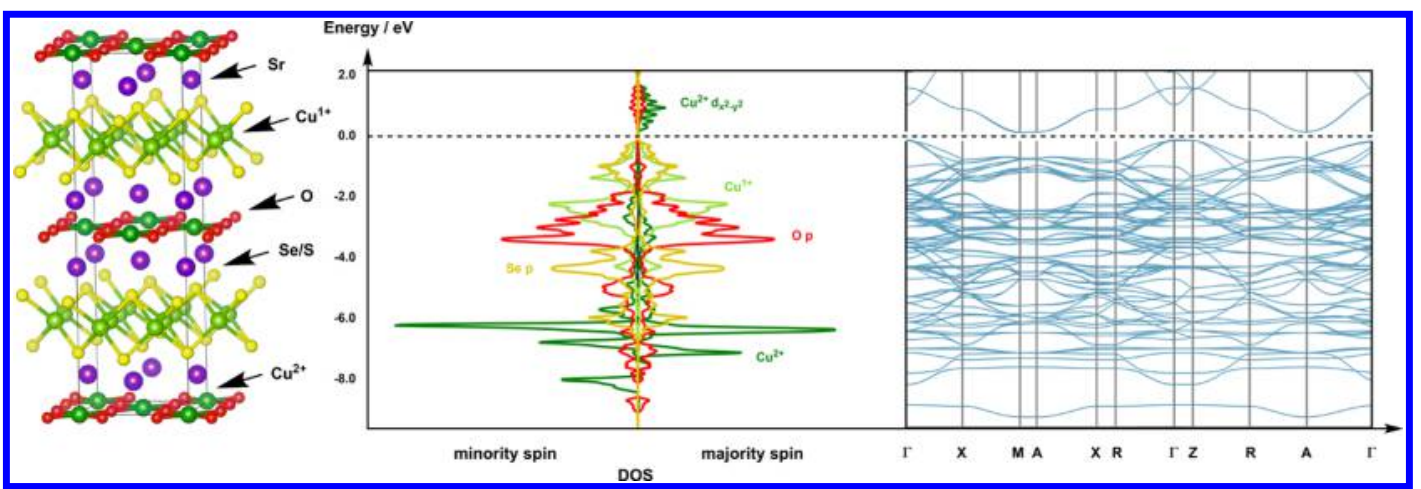

Figure 7. DOS and band structure for the atomic force microscopy ground state of $\mathrm{Sr}_{2} \mathrm{CuO}_{2} \mathrm{Cu}_{2} \mathrm{Se}_{2}$ using a $\sqrt{ } 2 a \times \sqrt{ } 2 a \times c$ expansion of the unit cell.

for $\mathrm{Sr}_{2} \mathrm{CuO}_{2} \mathrm{Cu}_{2} \mathrm{Se}_{2}$ is also very similar to that reported by Weng et al. for $\mathrm{Sr}_{2} \mathrm{CuO}_{2} \mathrm{Cl}_{2}$, ${ }^{29}$ although the $3 \mathrm{p}$ band of the more electronegative chloride ions lie more than $2 \mathrm{eV}$ below the empty $\mathrm{Cu}^{2+} 3 \mathrm{~d}_{x}{ }^{2}-y^{2}$ conduction band in the latter. As a result, $\mathrm{Sr}_{2} \mathrm{CuO}_{2} \mathrm{Cl}_{2}$ is a large band gap charge transfer insulator, consistent with its large measured resistivity. ${ }^{16}$ In $\mathrm{Sr}_{2} \mathrm{CuO}_{2} \mathrm{Cu}_{2} \mathrm{Se}_{2}$, in contrast, the close proximity of the Se $4 \mathrm{p}$ valence band and the $\mathrm{Cu}^{2+} 3 \mathrm{~d}_{x^{2}-y^{2}}$ conduction band suggests that partial depopulation of the top of the valence band is possible. We note here that the band gap is also highly sensitive to the chosen value of $U_{\text {eff }}$ at $\mathrm{Cu}^{2+}$, and indeed with a smaller value of $4.0 \mathrm{eV}$, the bottom of the $\mathrm{Cu} \mathrm{d}_{x^{2}-y^{2}}$ band at $M$ / $A$ crosses the Fermi level and generates holes in the top of the Se $4 p$ valence band at $\Gamma$ and $Z$ (Supporting Information, Figure S13). On the basis of the calculations alone, we cannot therefore eliminate the possibility that spontaneous charge transfer generates holes in the valence band and that this leads to relatively low resistivity of $\mathrm{Sr}_{2} \mathrm{CuO}_{2} \mathrm{Cu}_{2} \mathrm{Se}_{2}$ compared to that of $\mathrm{Sr}_{2} \mathrm{CuO}_{2} \mathrm{Cl}_{2}$. By way of the precedent, a number of compounds are known, in which copper chalcogenide layers contain less-than-fully-reduced chalcogenide ions, including $\mathrm{TlCu}_{2} \mathrm{Se}_{2},{ }^{41} \mathrm{KCu}_{4} \mathrm{~S}_{3},{ }^{42} \mathrm{Na}_{1.9} \mathrm{Cu}_{2} \mathrm{OCu}_{2} \mathrm{Se}_{2},{ }^{43} \mathrm{Bi}_{2} \mathrm{YO}_{4} \mathrm{Cu}_{2} \mathrm{Se}_{2}$, and derivatives of $\mathrm{Sr}_{2} \mathrm{ZnO}_{2} \mathrm{Cu}_{2} \mathrm{~S}_{2}$, in which $\mathrm{Sr}$ is substituted by some $\mathrm{K}$ to introduce holes in the valence band. ${ }^{45}$ In all these cases, the chalcogenide is formally oxidized by up to half an electron without forming $\mathrm{Ch}-\mathrm{Ch}$ bonds, leading to metallic behavior. The fact that $\mathrm{Sr}_{2} \mathrm{CuO}_{2} \mathrm{Cu}_{2} \mathrm{Se}_{2}$ and $\mathrm{Ba}_{2} \mathrm{CuO}_{2} \mathrm{Cu}_{2} \mathrm{Se}_{2}$ do not show metallic conductivity and that the localized moment found for $\mathrm{Sr}_{2} \mathrm{CuO}_{2} \mathrm{Cu}_{2} \mathrm{Se}_{2}$ using PND is comparable to that found for $\mathrm{Sr}_{2} \mathrm{CuO}_{2} \mathrm{Cl}_{2}$ suggests that the degree of electron transfer from selenide to $\mathrm{Cu}^{2+}$ is very small under ambient conditions. It remains possible, however, that isovalent substitution or a relatively small external pressure may change the electronic state significantly.

\section{CONCLUSIONS}

Stoichiometric $\mathrm{Sr}_{2} \mathrm{CuO}_{2} \mathrm{Cu}_{2} \mathrm{Se}_{2}$ is a narrow band gap semiconductor system with a small localized moment on the $\mathrm{Cu}^{2+}$ ions in the oxide layers. It bears many similarities to the relatives or parents of cuprate superconductors such as $\mathrm{La}_{2} \mathrm{CuO}_{4}$ or $\mathrm{Sr}_{2} \mathrm{CuO}_{2} \mathrm{Cl}_{2}$, but the selenide-dominated valence band lies very close to the unoccupied $\mathrm{Cu}^{2+}$ levels of the conduction band, offering the prospect of chemical tuning, perhaps to introduce superconductivity. The sulfide analogue $\mathrm{Sr}_{2} \mathrm{CuO}_{2} \mathrm{Cu}_{2} \mathrm{~S}_{2}$ presents synthetic challenges, but calculations on this phase reproduce the structural parameters obtained from an impure sample and suggest that its band structure and physical properties are similar to those of the selenide.

\section{ASSOCIATED CONTENT}

\section{Supporting Information}

The Supporting Information is available free of charge on the ACS Publications website at DOI: 10.1021/acs.inorgchem.8b02698.

Plots and tables showing the results of powder diffraction analysis, detailed analysis of the magnetic model, additional magnetometry measurements, and additional computational results (PDF)

\section{AUTHOR INFORMATION}

\section{Corresponding Author}

*E-mail: simon.clarke@chem.ox.ac.uk.

\section{Author Contributions}

J.N.B. and C.F.S. synthesized the samples and collected and analyzed the experimental data with help from S.J. Cassidy and D.N.W. J.E.M. and S.L. performed and interpreted the band structure calculations. S.J. Clarke and J.N.B. conceived the project and wrote the paper with input from the other authors.

\section{Notes}

The authors declare no competing financial interest.

\section{ACKNOWLEDGMENTS}

We acknowledge the financial support of the EPSRC (grants EP/P018874/1 and EP/M020517/1 and studentship support for J.N.B. and C.F.S.). We thank the ISIS facility for the award of beam time on WISH and the Diamond Light Source Ltd for the award of beam time on I11 (allocation EE18786) and for studentship support for J.N.B. S.L. acknowledges financial support from the China Scholarship Council (CSC). We thank Dr C. Murray, Dr S. Day, and Dr A. Baker for assistance on I11, Dr P. Manuel and Dr F. Orlandi for assistance on WISH, and Dr. R. I. Smith for assistance on POLARIS.

\section{REFERENCES}

(1) Zhu, W. J.; Hor, P. H. Unusual Layered Transition-Metal Oxysulfides: $\mathrm{Sr}_{2} \mathrm{Cu}_{2} \mathrm{MO}_{2} \mathrm{~S}_{2}(\mathrm{M}=\mathrm{Mn}, \mathrm{Zn})$. L. Solid State Chem. 1997, 130, 319-321.

(2) Zhu, W. J.; Hor, P. H.; Jacobson, A. J.; Crisci, G.; Albright, T. A.; Wang, S.-H.; Vogt, T. $\mathrm{A}_{2} \mathrm{Cu}_{2} \mathrm{CoO}_{2} \mathrm{~S}_{2}(\mathrm{~A}=\mathrm{Sr}, \mathrm{Ba})$, A Novel Example of a Square-Planar $\mathrm{CoO}_{2}$ Layer. L. Am. Chem. Soc. 1997, 119, 1239812399. 
(3) Brechtel, E.; Cordier, G.; Schäfer, H. Über Oxidpnictide: Zur Kenntnis von $\mathrm{A}_{2} \mathrm{Mn}_{3} \mathrm{~B}_{2} \mathrm{O}_{2}$ mit $\mathrm{A}=\mathrm{Sr}$, $\mathrm{Ba}$ und $\mathrm{B}=\mathrm{As}, \mathrm{Sb}, \mathrm{Bi} / \mathrm{On}$ Oxidpnictides: Preparation and Crystal Structure of $\mathrm{A}_{2} \mathrm{Mn}_{3} \mathrm{~B}_{2} \mathrm{O}_{2}$ with $\mathrm{A}=\mathrm{Sr}, \mathrm{Ba}$ and B = As, Sb, Bi. Z. Naturforsch. Sect. B 1979, 34, 777780.

(4) Stock, C.; McCabe, E. E. The magnetic and electronic properties of oxyselenides-influence of transition metal ions and lanthanides. $I$. Phvs.: Condens. Mat. 2016, 28, 453001.

(5) Gál, Z. A.; Rutt, O. J.; Smura, C. F.; Overton, T. P.; Barrier, N.; Clarke, S. J.; Hadermann, J. Structural Chemistry and Metamagnetism of an Homologous Series of Layered Manganese Oxysulfides. I. Am. Chem. Soc. 2006, 128, 8530-8540.

(6) Adamson, P.; Hadermann, J.; Smura, C. F.; Rutt, O. J.; Hyett, G.; Free, D. G.; Clarke, S. J. Competing Magnetic Structures and the Evolution of Copper Ion/Vacancy Ordering with Composition in the Manganite Oxide Chalcogenides $\mathrm{Sr}_{2} \mathrm{MnO}_{2} \mathrm{Cu}_{1.5}\left(\mathrm{~S}_{1-\mathrm{x}} \mathrm{Se}_{\mathrm{x}}\right)_{2}$. Chem. Mater. 2012, 24, 2802-2816.

(7) Blandy, J. N.; Abakumov, A. M.; Christensen, K. E.; Hadermann, J.; Adamson, P.; Cassidy, S. J.; Ramos, S.; Free, D. G.; Cohen, H.; Woodruff, D. N.; Thompson, A. L.; Clarke, S. J. Soft chemical control of the crystal and magnetic structure of a layered mixed valent manganite oxide sulfide. APL Mater. 2015, 3, 041520.

(8) Hirose, H.; Ueda, K.; Kawazoe, H.; Hosono, H. Electronic Structure of $\mathrm{Sr}_{2} \mathrm{Cu}_{2} \mathrm{ZnO}_{2} \mathrm{~S}_{2}$ Layered Oxysulfide with $\mathrm{CuS}$ Layers. Chem. Mater. 2002, 14, 1037-1041.

(9) Clarke, S. J.; Adamson, P.; Herkelrath, S. J. C.; Rutt, O. J.; Parker, D. R.; Pitcher, M. J.; Smura, C. F. Structures, physical properties, and chemistry of layered oxychalcogenides and oxypnictides. Inorg. Chem. 2008, 47, 8473-8486.

(10) Smura, C. F.; Parker, D. R.; Zbiri, M.; Johnson, M. R.; Gál, Z. A.; Clarke, S. J. High-Spin Cobalt(II) Ions in Square Planar Coordination: Structures and Magnetism of the Oxysulfides $\mathrm{Sr}_{2} \mathrm{CoO}_{2} \mathrm{Cu}_{2} \mathrm{~S}_{2}$ and $\mathrm{Ba}_{2} \mathrm{CoO}_{2} \mathrm{Cu}_{2} \mathrm{~S}_{2}$ and Their Solid Solution. I. Am. Chem. Soc. 2011, 133, 2691-2705.

(11) Herkelrath, S. J. C.; Blandy, J. N.; Clarke, S. J. Magnetic ordering in the layered oxyselenides $\mathrm{Sr}_{2} \mathrm{CoO}_{2} \mathrm{Ag}_{2} \mathrm{Se}_{2}$ and $\mathrm{Ba}_{2} \mathrm{CoO}_{2} \mathrm{Ag}_{2} \mathrm{Se}_{2}$. I. Solid State Chem. 2018, 264, 119-123.

(12) Li, W.; Fu, Z.; Wang, X.; Zhang, J.; Liu, M.; Zhao, J.; Jin, M.; Zhao, G.; Dai, G.; Deng, Z.; Zhang, S.; Feng, S.; Hu, Z.; Huang, Q.; Lin, H.; Chen, C.-T.; Yang, Y.; Jin, C. Synthesis, Structure, and Properties of the Layered Oxyselenide $\mathrm{Ba}_{2} \mathrm{CuO}_{2} \mathrm{Cu}_{2} \mathrm{Se}_{2}$. Inorg. Chem. 2018, 57, 5108-5113.

(13) Zhou, T.; Wang, Y.; Jin, S.; Li, D.; Lai, X.; Ying, T.; Zhang, H.; Shen, S.; Wang, W.; Chen, X. Structures and Physical Properties of Layered Oxyselenides $\mathrm{Ba}_{2} \mathrm{MO}_{2} \mathrm{Ag}_{2} \mathrm{Se}_{2}(\mathrm{M}=\mathrm{Co}, \mathrm{Mn})$. Inorg. Chem. 2014, 53, 4154-4160.

(14) Jin, S.; Chen, X.; Guo, J.; Lei, M.; Lin, J.; Xi, J.; Wang, W.; Wang, W. $\mathrm{Sr}_{2} \mathrm{Mn}_{3} \mathrm{Sb}_{2} \mathrm{O}_{2}$ Type Oxyselenides: Structures, Magnetism, and Electronic Properties of $\mathrm{Sr}_{2} \mathrm{AO}_{2} \mathrm{M}_{2} \mathrm{Se}_{2}(\mathrm{~A}=\mathrm{Co}, \mathrm{Mn} ; \mathrm{M}=\mathrm{Cu}, \mathrm{Ag}$ ). Inorg. Chem. 2012, 51, 10185-10192.

(15) Bednorz, J. G.; Müller, K. A. Possible high $T_{\mathrm{c}}$ superconductivity in the $\mathrm{Ba}-\mathrm{La}-\mathrm{Cu}-\mathrm{O}$ system. Z. Phys. B Condens. Mat. 1986, 64, 189-193.

(16) Miller, L. L.; Wang, X. L.; Wang, S. X.; Stassis, C.; Johnston, D. C.; Faber, J.; Loong, C.-K. Synthesis, structure, and properties of $\mathrm{Sr}_{2} \mathrm{CuO}_{2} \mathrm{Cl}_{2}$. Phvs. Rev. B: Condens. Matter Mater. Phvs. 1990, 41, 1921-1925.

(17) Otzschi, K.; Ogino, H.; Shimoyama, J.-i.; Kishio, K. New candidates for superconductors; A series of layered oxysulfides $\left(\mathrm{Cu}_{2} \mathrm{~S}_{2}\right)\left(\mathrm{Sr}_{\mathrm{n}+1} \mathrm{MnO}_{3 \mathrm{n}-1}\right)$. I. Low Temp. Phvs. 1999, 117, 729-733.

(18) Thompson, S. P.; Parker, J. E.; Potter, J.; Hill, T. P.; Birt, A.; Cobb, T. M.; Yuan, F.; Tang, C. C. Beamline I11 at Diamond: A new instrument for high resolution powder diffraction. Rev. Sci. Instrum. 2009, 80, 075107.

(19) Williams, W. G.; Ibberson, R. M.; Day, P.; Enderby, J. E. GEM General materials diffractometer at ISIS. Phys. B 1997, 241-243, 234-236.
(20) Hull, S.; Smith, R. I.; David, W. I. F.; Hannon, A. C.; Mayers, J.; Cywinski, R. The Polaris powder diffractometer at ISIS. Phys. B 1992, 180-181, 1000-1002.

(21) Chapon, L. C.; Manuel, P.; Radaelli, P. G.; Benson, C.; Perrott, L.; Ansell, S.; Rhodes, N. J.; Raspino, D.; Duxbury, D.; Spill, E.; Norris, J. WISH: The New Powder and Single Crystal Magnetic Diffractometer on the Second Target Station. Neutron News 2011, 22, $22-25$.

(22) Coelho, A. A. TOPAS, Academic version 5; Coelho Software: Brisbane, Australia, 2012.

(23) Kresse, G.; Furthmüller, J. Efficient iterative schemes for ab initio total-energy calculations using a plane-wave basis set. Phvs. Rev. B: Condens. Matter Mater. Phvs. 1996, 54, 11169-11186.

(24) Kresse, G.; Hafner, J. Ab initio molecular dynamics for liquid metals. Phvs. Rev. B: Condens. Matter Mater. Phvs. 1993, 47, 558-561.

(25) Perdew, J. P.; Burke, K.; Wang, Y. Generalized gradient approximation for the exchange-correlation hole of a many-electron system. Phys. Rev. B: Condens. Matter Mater. Phys. 1996, 54, 1653316539.

(26) Monkhorst, H. J.; Pack, J. D. Special points for Brillouin-zone integrations. Phys. Rev. B: Condens. Matter Mater. Phys. 1976, 13, $5188-5192$.

(27) Blöchl, P. E. Projector augmented-wave method. Phys. Rev. B: Condens. Matter Mater. Phvs. 1994, 50, 17953-17979.

(28) Dudarev, S. L.; Botton, G. A.; Savrasov, S. Y.; Humphreys, C. J.; Sutton, A. P. Electron-energy-loss spectra and the structural stability of nickel oxide: An LSDA+U study. Phys. Rev. B: Condens. Matter Mater. Phys. 1998, 57, 1505-1509.

(29) Weng, H.; Wan, X.; Zhou, J.; Dong, J. Electronic structure and linear optical properties of $\mathrm{Sr}_{2} \mathrm{CuO}_{2} \mathrm{Cl}_{2}$ studied from the first principles calculation. Eur. Phvs. I. B 2003, 35, 217-221.

(30) Shannon, R. D. Revised effective ionic radii and systematic studies of interatomic distances in halides and chalcogenides. Acta Crystallogr., Sect. A: Cryst. Phys., Diffr., Theor. Gen. Crystallogr. 1976, 32, 751-767.

(31) Burns, P. C.; Hawthorne, F. C. Tolbachite, $\mathrm{CuCl}_{2}$, The 1st Example of $\mathrm{Cu}^{2+}$ Octahedrally Coordinated by Cl. Am. Mineral. 1993, $78,187-189$

(32) Oeckler, O.; Simon, A. Redetermination of the crystal structure of copper dibromide, $\mathrm{CuBr}_{2}$. Z. Kristallogr. 2000, 215, 13.

(33) Grande, B.; Müller-Buschbaum, H. Über Oxocuprate. XVIII. Zur Kenntnis von $\mathrm{Sr}_{2} \mathrm{CuO}_{2} \mathrm{Br}_{2}$ mit einem Beitrag über $\mathrm{La}_{2} \mathrm{NiO}_{4}$. $\underline{Z}$. Anorg. Allg. Chem. 1977, 433, 152-156.

(34) Bain, G. A.; Berry, J. F. Diamagnetic Corrections and Pascal's Constants. I. Chem. Educ. 2008, 85, 532.

(35) Gregory, S. Magnetic Susceptibility of Oxygen Adsorbed on Graphite. Phys. Rev. Lett. 1978, 40, 723-725.

(36) Vaknin, D.; Sinha, S. K.; Stassis, C.; Miller, L. L.; Johnston, D. C. Antiferromagnetism in $\mathrm{Sr}_{2} \mathrm{CuO}_{2} \mathrm{Cl}_{2}$. Phvs. Rev. B: Condens. Matter Mater. Phvs. 1990, 41, 1926-1933.

(37) Campbell, B. J.; Stokes, H. T.; Tanner, D. E.; Hatch, D. M. ISODISPLACE: a web-based tool for exploring structural distortions. I. Appl. Crvstallogr. 2006, 39, 607-614.

(38) Magnetic Group Tables; Litvin, D. B., Ed.; International Union of Crystallography: Chester, England, 2013; DOI: 10.1107/ 9780955360220001.

(39) Opechowski, W.; Guccione, R. Magnetism; Academic Press: New York, 1965; Vol. 2.

(40) Shirane, G.; Endoh, Y.; Birgeneau, R. J.; Kastner, M. A.; Hidaka, Y.; Oda, M.; Suzuki, M.; Murakami, T. Two-dimensional antiferromagnetic quantum spin-fluid state in $\mathrm{La}_{2} \mathrm{CuO}_{4}$. Phvs. Rev. Lett. 1987, 59, 1613-1616.

(41) Berger, R.; Van Bruggen, C. F. $\mathrm{TlCu}_{2} \mathrm{Se}_{2}$ : A p-type metal with a layer structure. L. Less-Common Met. 1984, 99, 113-123.

(42) Brown, D. B.; Zubieta, J. A.; Vella, P. A.; Wrobleski, J. T.; Watt, T.; Hatfield, W. E.; Day, P. Solid-state structure and electronic properties of a mixed-valence two-dimensional metal, potassium copper sulfide $\left(\mathrm{KCu}_{4} \mathrm{~S}_{3}\right)$. Inorg. Chem. 1980, 19, 1945-1950. 
(43) Park, Y.; DeGroot, D. C.; Schindler, J. L.; Kannewurf, C. R.; Kanatzidis, M. G. Intergrowth of two different layered networks in the metallic copper oxyselenide $\mathrm{Na}_{1.9} \mathrm{Cu}_{2} \mathrm{Se}_{2} \cdot \mathrm{Cu}_{2} \mathrm{O}$. Chem. Mater. 1993, 5, $8-10$.

(44) Evans, J. S. O.; Brogden, E. B.; Thompson, A. L.; Cordiner, R. L. Synthesis and characterisation of the new oxyselenide $\mathrm{Bi}_{2} \mathrm{YO}_{4} \mathrm{Cu}_{2} \mathrm{Se}_{2}$. Chem. Commun. 2002, 912-913.

(45) Ueda, K.; Hirose, S.; Kawazoe, H.; Hosono, H. Electrical and Optical Properties of Layered Oxysulfides with $\mathrm{CuS}$ Layers: $\mathrm{Sr}-\mathrm{Cu}-$ $\mathrm{M}-\mathrm{O}-\mathrm{S}$ System $(\mathrm{M}=\mathrm{Zn}, \mathrm{Ga}, \mathrm{In})$. Chem. Mater. 2001, 13, 18801883. 